"نشريه علوم زراعى ايران"

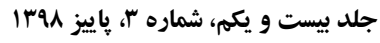

مقاله يُوهشى

اثر منبع كود نيتروزن بر عملكرد و اسانس ريحان (Ocimum basilicum L.) و عملكرد ذرت علوفهاى (Zea mays L.) در كشت مخلود

Effect of nitrogen fertilizer source on yield and essential oil content of sweet basil (Ocimum basilicum L.) and forage maize (Zea mays L.) yield in intercropping

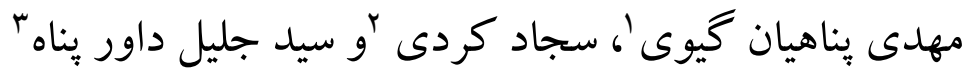

جيده

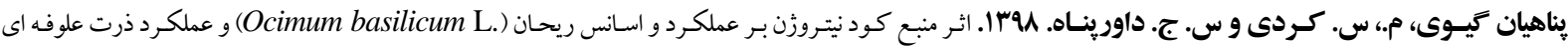
(Zea mays L.)

به منظور ارزيابى اثر منبع كود نيتروزن بر عملكرد و كيفيت ريحان و محصول علوفه ذرت در كشت مخلـوط (سـرى افزايشى)، آزمايشى در طى سالهاى زراعى سو-1 در مزرعه تحقيقاتى دانشكاه لرستان اجرا شد. تيمارهاى آزمايشى شامل كود نيتروزن در جهار سطح: عدم مصرف كود (شاهد)، كود نيتروزن، كود زيستى نيتروكسين و مصرف تلفيقى (•0 درصد كود نيتروزن + نيتروكسين) و نسبتهاى كاشت شـامل: كثـت خـالص ريحان (رقم مبار كه)، كشت خالص ذرت علوفهاى (رقم سينكل كراس ع.Y)، كشت مخلوط ذرت علوفهاى+ Y م درصد ريحان، كشت

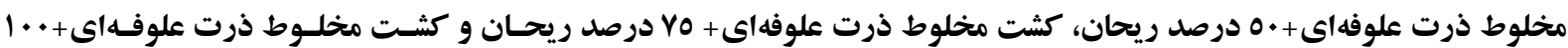
درصد ريحان بودند. نتايج نشان داد كه بيشترين وزن خشك ريحان (1/9 / همر اه با مصرف كود نيتروزن در برداشت دوم و در سال دوم آزمايش بود. بيشترين وزن خشـك علوفـه ذرت (•rarr آكيلـوكرم در هكتار) نيز از كشت خالص ذرت بدست آمد. مصرف تلفيقى •0 درصد كود نيتروزن + نيتروكسين در كشت مخلـوط باعـث افـزايش عملكرد زيستى و اسانس كياه ريحان شد. بيشترين ميزان نسبت برابرى زمين (1/07) در هر دو سال زراعى مربوط بـه كثـت مخلـوط ذرت علوفهاى ++· إ درصد ريحان همراه با مصرف كود زيستى نيتروكسين بود. نتايج اين آزمايش نشان داد كه حذف نيمى از كـود شيميايى نيتروزن و جايكزين كردن آن با كود زيستى نيتروكسين، راهكار مناسبى براى كاهش مصرف كودهـاى شـيميايى در كشـت مخلوط ريحان و ذرت علوفهاى و در راستاى اهداف كشاورزى پايدار مىباشد.

وازههاى كليدى: نسبتهاى كشت مخلوط، ذرت، ريحان، كود زيستى و نسبت برابرى زمين.

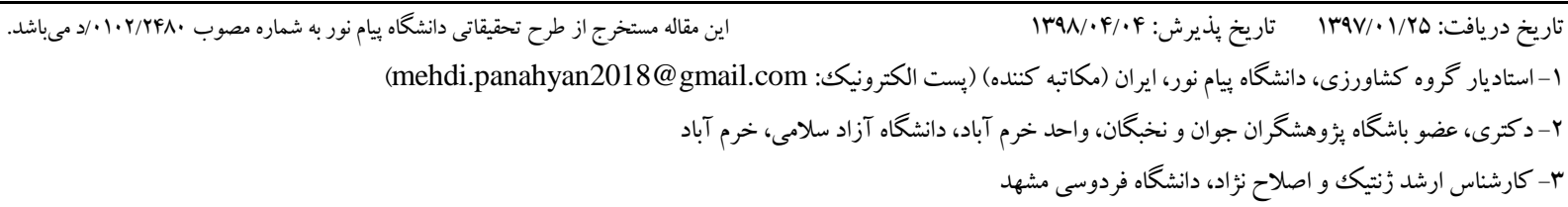


بذرهاى ريحان تلقيح شده با باكترى آزوسيريلوم باعث افزايش وزن تر و خشكك شاخساره، ارتفاع بوته و تعـداد شاخه جانبى نسبت به بو تههاى شاهد شد.

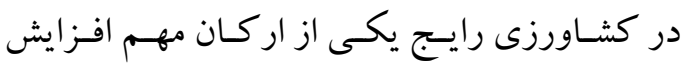

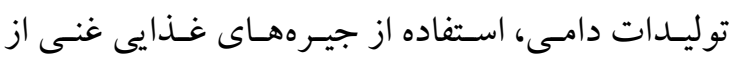

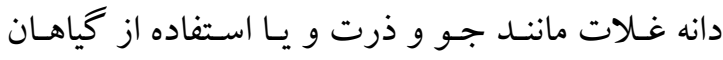

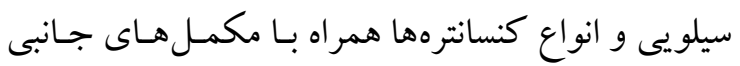

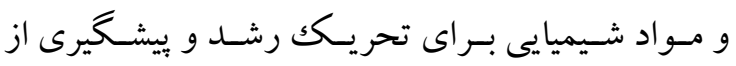
بـروز بيمـارىهـا اسـت. اسـتفاده بـى رويـه از تركيبـات

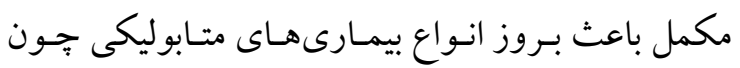
اسـيدوز و آبسـهاى كبـدى در دامهـاى نشـخو ار كننده

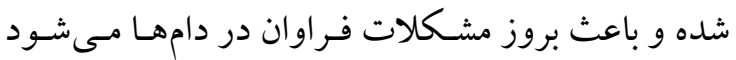
(McGuirk and Semard, 2005) باعـث شــده اسـت كـه در دهـهـهـاى اخيـر توجـهـ بــه

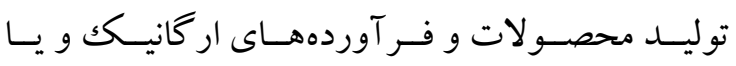

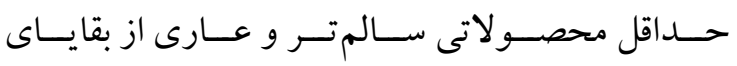

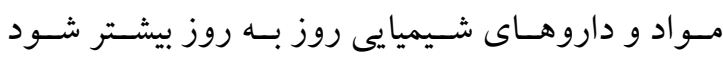

.(Koochaki and Khajeh Hosseini, 2008)

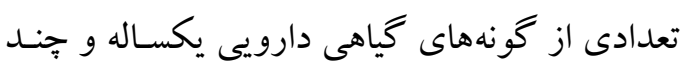
ساله كه به خودى خود و به دلايل گوناكونى جون خون غير

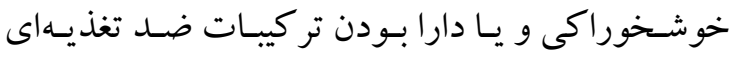

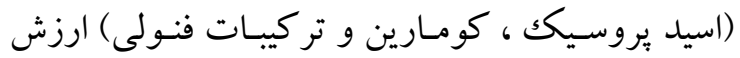

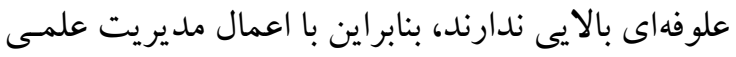

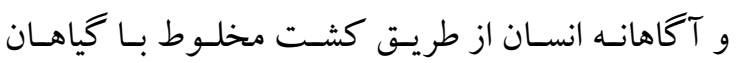
علوفهاى رايج مى توان علوفهاى بـا كميـت بـالا و ارزش دارويى فراوان توليد كرد كه در اين راستا ايدهاى جديد

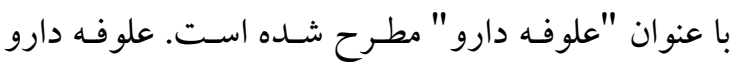

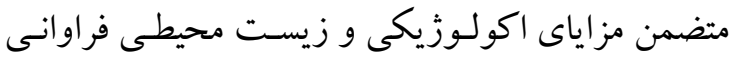

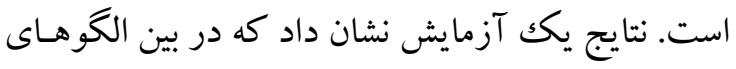

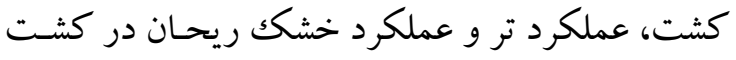

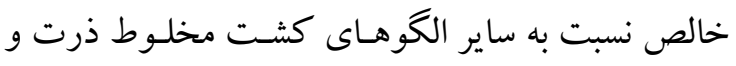
ريحـان بيشتر بـود (Bagheri et al., 2014). نتـايج سـاير

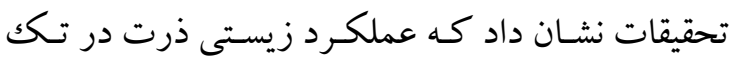

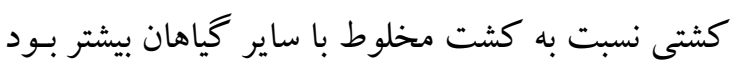

\section{مقدمه}

مصسرف كودهـاى شـيميايى از جملـه نيتـروزن تـا

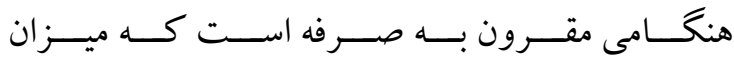

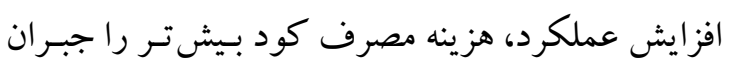

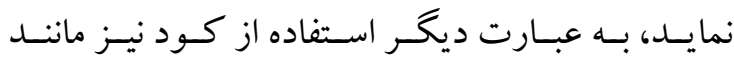

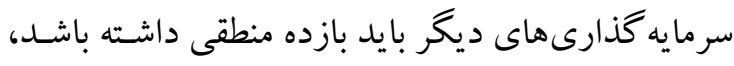

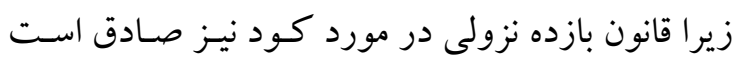

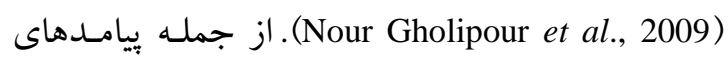

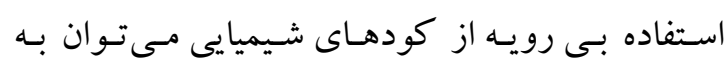

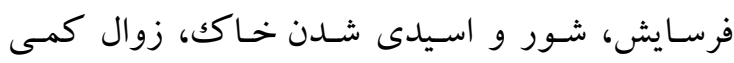

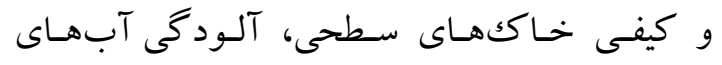

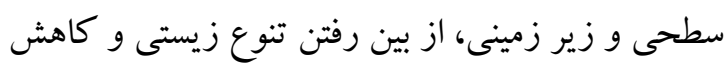

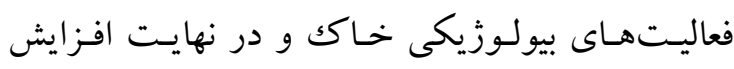

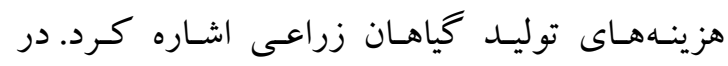
كشاورزى بايدار تأمين عناصر غذايى مورد نياز گياهـان

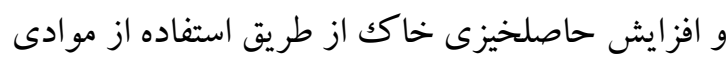

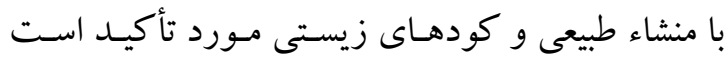
(Chen et al., 2014; Vessey, 2003) كودهاى زيستى به علل مختلـف در سـالهـاى كذشـته

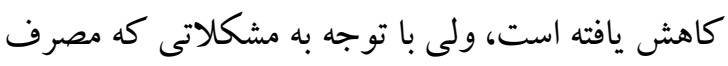
بى رويه كودهاى شيميايى به وجـود آورده، استففاده از

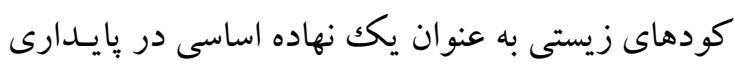

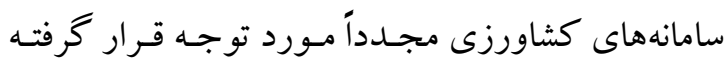
است (Alexandratos, 2003). يكـى از راههـاى كـاهش مصسرف كـود نيتــروزن

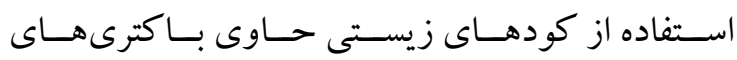

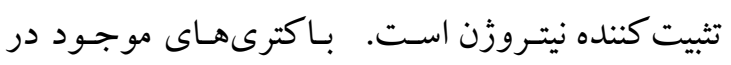
كودهاى زيستى علاوه بر تثبيت نيتـروزن هـوا و متعـادل

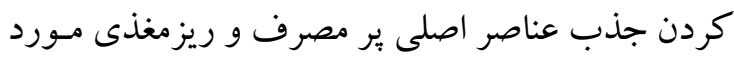

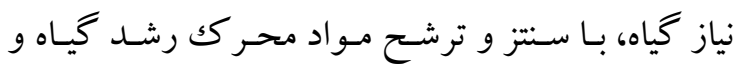

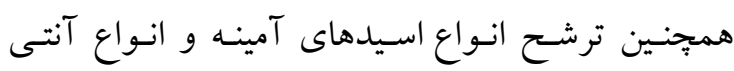
بيوتيككها باعث رشد و توسعه ريشه و اندام هوايى كياه

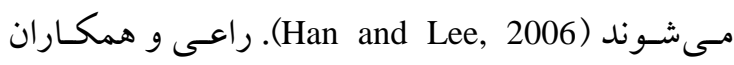

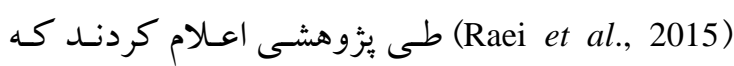




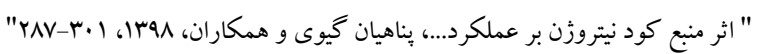

علوفهاى، در كشت مخلـوط ايسن دو كيـاه و در راستاى كشاورزى يايدار انجام شد.

\section{مواد و روشها}

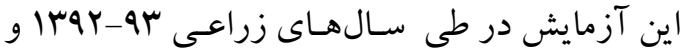
P دانشخاه لرستان با طول جغر افيايى FA درجه و Y F دقيقـه شرقى و عرض جغر افيايى سr درجه و و و دقيقـه شـمالى

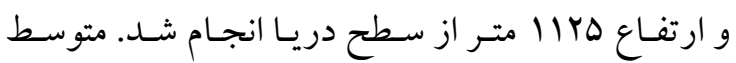
بارند اقليم اين شهرستان طبق طبقهبندى اقليمى دومـارتن نيمـهـ

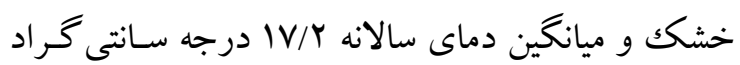
است. براى تعيين ويز كى هاى فيزيكى و شيميايى خـاكك محل اجراى آزمايش، در هر دو سال آزمـايش از عمـق صـفر تـا ·F سـانتى متـرى، نمونسه مر كـب از شـش نقطه تصادفى تهيه شد. خصوصيات فيزيكى و شيميايى خاكك در جدول ال ارائه شده است. آزمـايش بـه صـورت فاكتوريـل و در قالـب طـرح
.(Ghanbari et al., 2010; Ghanbari et al., 2006) ريحـان (Ocimum basilicum L.) كيـاهى علفى و يـك

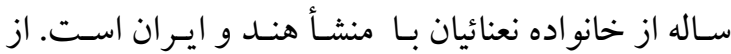
ريحان به عنوان دارويى، ادويهاى و سبزى تـازه استفاده

مىشود (Omidbaigi, 2006). در يزووهش حاضـر ذرت بـه عنـوان بايسه علوفـهاى و ريحان نيز بهدليل خو اص دارويى از جمله خاصيت ضد نفخى براى جلو كيرى از نفخ ايجاد شده توسـط علوفـه، شير افزايى و ضد استاسم و آرام بخش بـودن عـلاوه بـر افزايش كيفيت علوفه، جهت تأمين علوفه دارو با توليـد زيست توده بالا براى افزايش عملكرد علوفه در كشـت مخلوط با ذرت علوفهاى انتخاب شد. در رابطهه بـا تـأثير كودهـاى نيتروزنـى (زيسـتى، شـيميايى و تلفيقـى) بـر

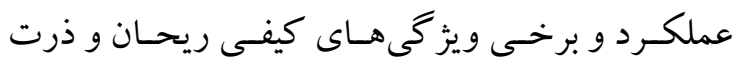
علوفهاى در كشت مخلوط افزايشـى اطلاعـات جنــدانى در دست نيسـت. از ايـن رو، آزمـايش حاضـر بـا هـدف كاهش مصرف كودهاى شيميايى و بررسى اثر مصسرف كودهاى زيسـتى بـر عملكـرد و كيفيـت ريحـان و ذرت

جدول ا-ويز كى هاى فيزيكى و شيميايى خاك محل اجراى آزمايش

Table 1. Physical and chemical properties of soil at the experiment site

\begin{tabular}{|c|c|c|c|c|c|c|c|}
\hline $\begin{array}{c}\text { سال } \\
\text { Year }\end{array}$ & $\begin{array}{c}\text { عمق خاكك } \\
\text { Soil depth } \\
(\mathrm{cm})\end{array}$ & $\begin{array}{c}\text { بافت خاكs } \\
\text { Soil texture }\end{array}$ & $\begin{array}{l}\text { اسيديته } \\
\text { pH }\end{array}$ & $\begin{array}{c}\text { هدايت الكتريكى } \\
\text { EC } \\
\left(\mathrm{dS} . \mathrm{m}^{-1}\right) \\
\end{array}$ & $\begin{array}{c}\text { نيتروزن كل } \\
\text { Total N } \\
(\%)\end{array}$ & $\begin{array}{c}\text { فسفر قابل جذب } \\
\text { Available P } \\
\text { (mg.kg-1) }\end{array}$ & $\begin{array}{c}\text { يتاسيم قابل جذب } \\
\text { Available K } \\
\text { (mg.kg-1) }\end{array}$ \\
\hline $\begin{array}{l}\text { Irar } \\
2014\end{array}$ & $0-40$ & $\begin{array}{c}\text { لومى-رسى } \\
\text { Clay Loam }\end{array}$ & 7.17 & 0.459 & 0.302 & 8 & 390 \\
\hline $\begin{array}{l}\text { Irqf } \\
2015\end{array}$ & $0-40$ & $\begin{array}{c}\text { لومى-رسى } \\
\text { Clay Loam }\end{array}$ & 7.36 & 0.536 & 0.285 & 6 & 356 \\
\hline
\end{tabular}

علوفـهاى، كشـت مخلـوط ذرت علوفـهاى + ها درصـد

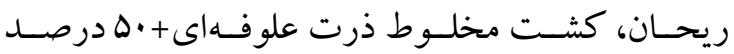
ريحسـان، كشـت مخلـوط ذرت علوفـهاى + VD درصــ ريحسان و كشـت مخلـوط ذرت علوفـهاى+...

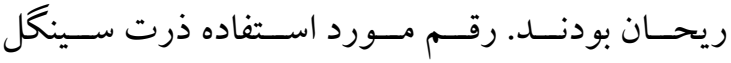
كراس F•V.F رقم ريحان مبار كه بود كه بذرهاى آنها از موسسه ياكان بذر اصفهان تهيه شدند.
بلو كك كامل تصادفى با سه تكـرار اجـرا شـد. تيمارهـاى

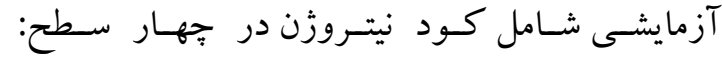
عدم مصرف كود زيستى و شـيميايى نيتـروزن (شـاهد)، كود نيتروزن (از منبـع اوره)، كـود زيسـتى نيترو كسـين (تلقـيح بـا بـذر) و مصـرف تلفيقى ( •ه درصـد كـود نيتـروزن + نيترو كسـين) و نسـبتهـاى كشـت مخلـوط شـامل: كشـت خـالص ريحــان، كشـت خـالص ذرت 
حدود دو هفته ييش از گللدهى ذرت استفاده شد.

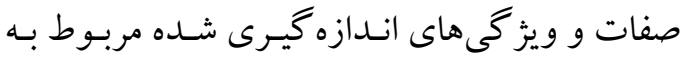
ذرت شامل وزن خشك برگك، وزن خشك بلال و وزن

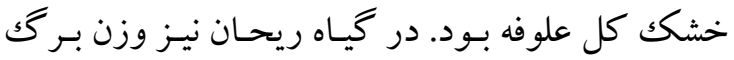

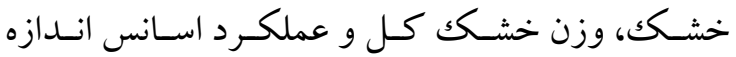
كرفته شدند. برداشت محصول ذرت ورت در مرحله خميـرى

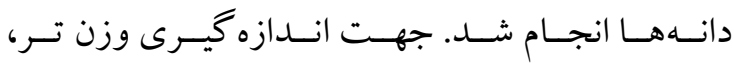
نمونهبردارى از دو رديف وسط بـه مسـاحت يـك متر

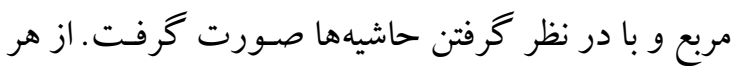

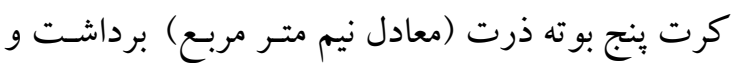

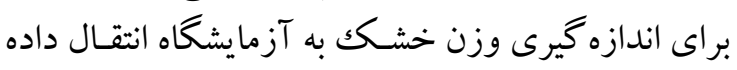

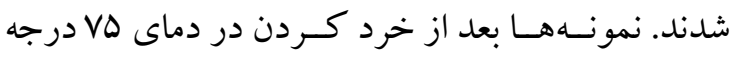

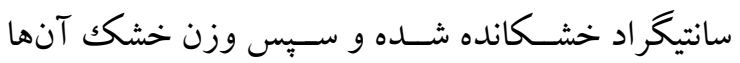
اندازه گيرى شد. برداشت گياه ريحان در سه جهين و در

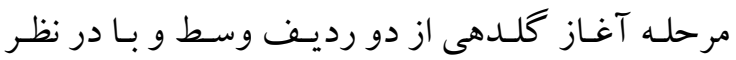

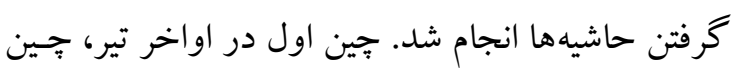
دوم در اوايــل شـهريور و جــين سـوم در اوايـلـ مهـر برداشت شدند. بوتههاى ريحـان در جـين اول و دوم در تمام طول دوره رشد همـراه بـا ذرت در مزرعـه حضور

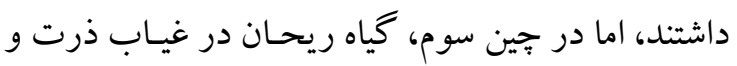
به تنهايى در مزرعه بود كه محصول آن در نيمه اول مهر برداشت شد. استخر اج اسانس ريحان بـا روش تقطيـر بـا

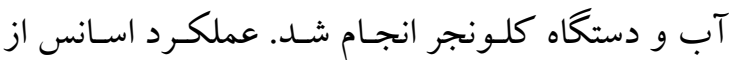
حاصلضرب درصـد اسـانس و عملكرد زيستى بدسـت

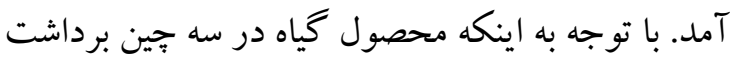

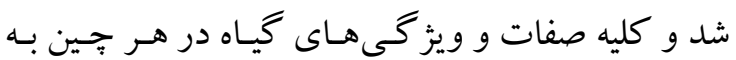

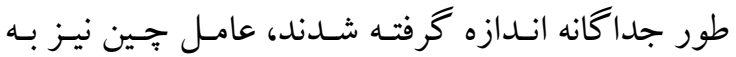
عنوان تيمار در نظر كرفته شد. بـه صورت فاكتوريـل و و در قالب طـرح كرتهـاى خـرد شــــه در زمان تجزيـه

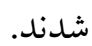
جهـت ارزيابى سودمندى كشت مخلوط نسـبت بـهـ كشت خـالص از شـاخص نسبت برابـرى زمسين (LER)

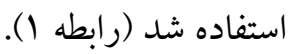
$\mathrm{LER}=\mathrm{LER}_{\mathrm{a}}+\mathrm{LER}_{\mathrm{b}}=\left(\frac{\mathrm{Yab}}{\mathrm{Yaa}}\right)+\left(\frac{\mathrm{Yba}}{\mathrm{Ybb}}\right) \quad$ (رابطه (1)
فاصله رديفهـاى كاشـت بـراى هـر دو گيـاه ذرت

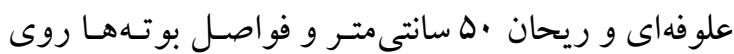
رديف در كليه نسبتهاى كاشـت بـراى ذرت علوفهـاى r r.

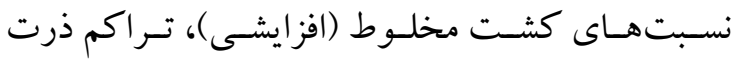

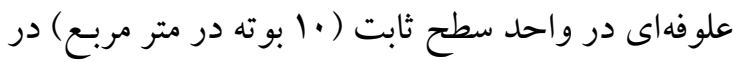

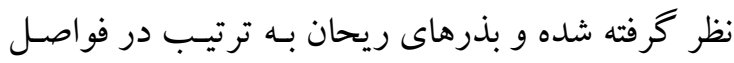

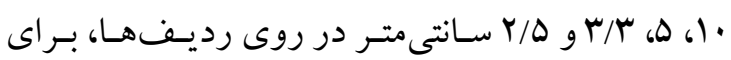

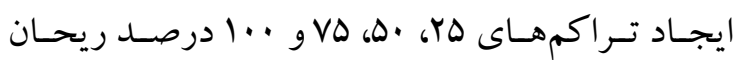

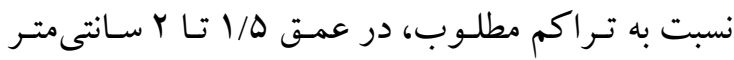

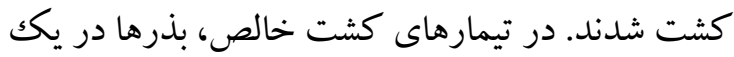

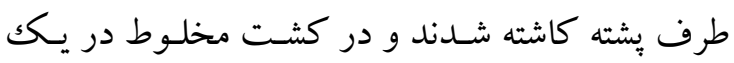
طرف بشته بذر ذرت و در طرف ديخـر آن بـذر ريحـان

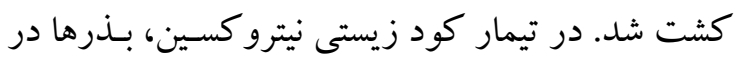
زمان كاشت بر اساس توصيه شـركت سـازنده (شـركت سترون

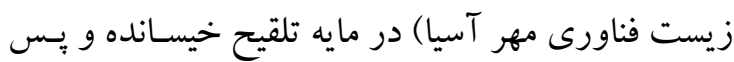

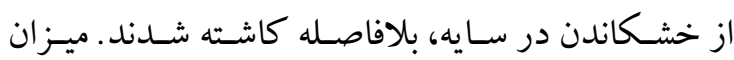

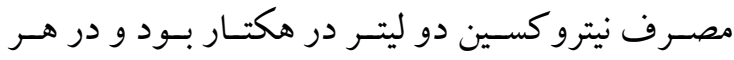

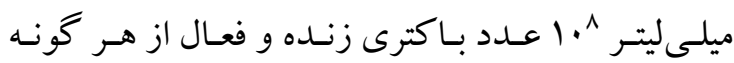
(ازتوباكتر و آزوسييريلوم) وجود داشـت. كشـت بـــرها

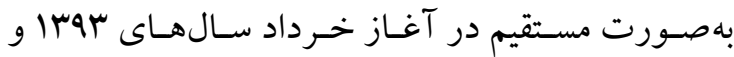

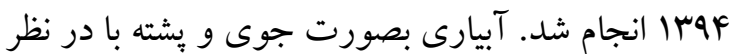

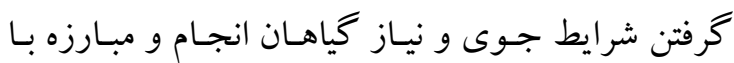

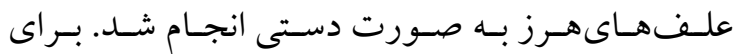
جلو گيرى از نشت نيتروزن، بين كرتهاى مجاء مجاور يـك

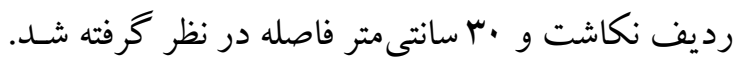

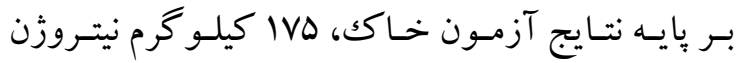

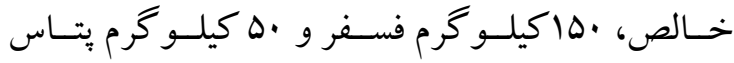
(بهترتيب از منـابع اوره، سويرفسفات تريبـل و سـولفات

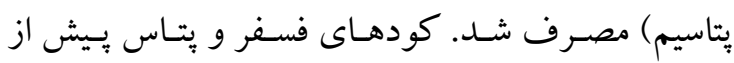

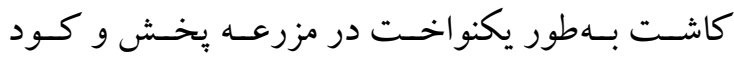

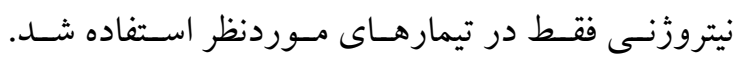

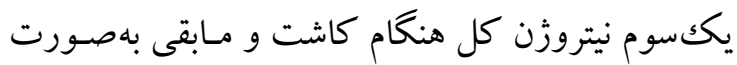

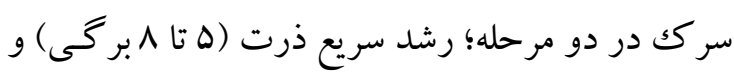




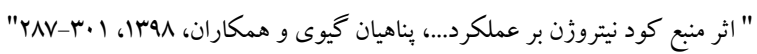

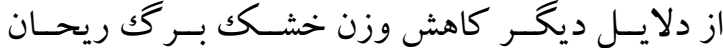
در نسبتهاى مخلوط نسبت به كشت خـالص، افزايش

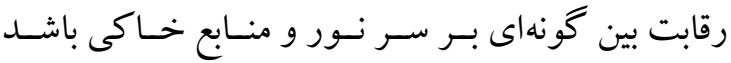

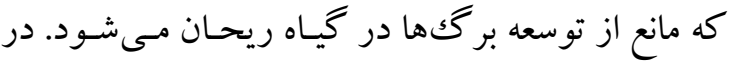
كشت مخلوط مرزه (Satureja hortensis L. Sو شبدر

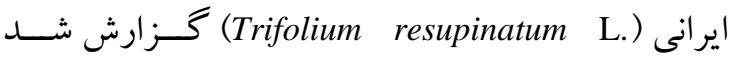
كه وزن خشك اندام رويشى مرزه در تيمارهاى كثــت

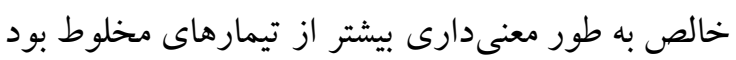
(Hasanzadeh Aval et al., 2010) در كليه نسبتهاى مخلوط و منابع كود نيتروزن افزايش ورن

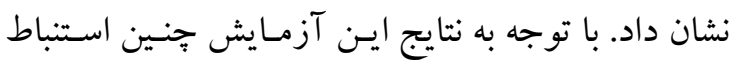

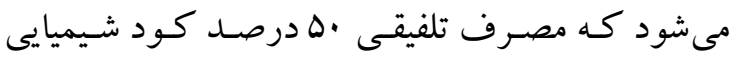

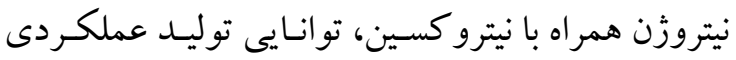

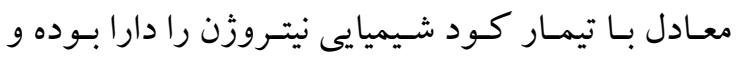

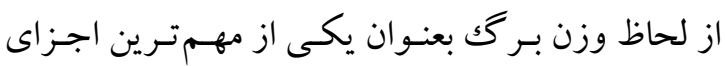

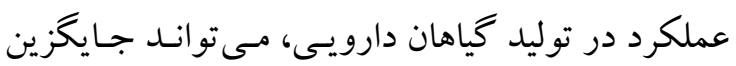

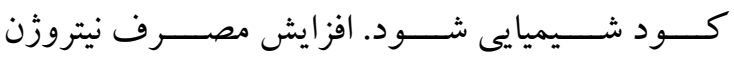

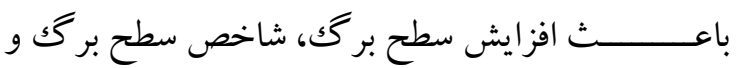

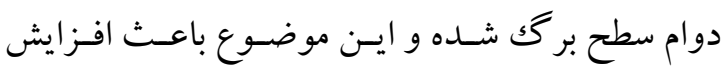

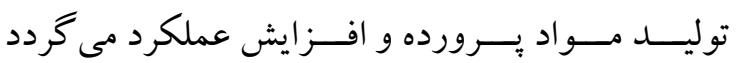

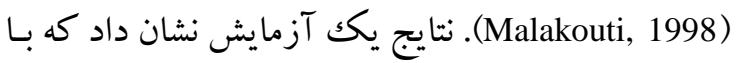

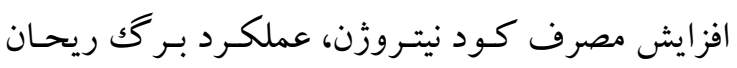

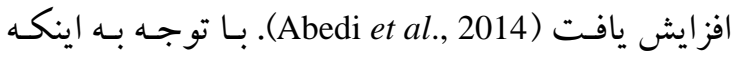
برداشت كليه جينهاى ريحان در مرحله رشدى يكسـان انجام شد، به نظر مىرسد كه در جين هاى دوم و سوم به دليل دماى مناسبتر هوا، دوره طولانى ترى بـراى رشـــ رويشى گياه نسبت به جين اول فراهم بوده و ييكـر كياه

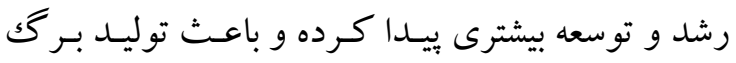

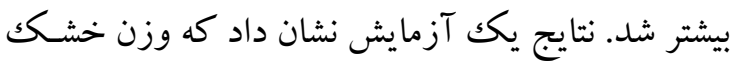

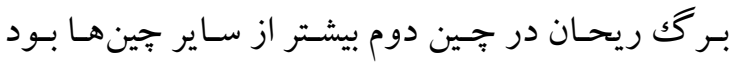
كه نتايج تحقيق حاضر را (Ghalichi Sofla et al., 2014) تاييد مى كند. نتايج تجزيه واريـانس مر كـب دادههـا نشـان داد كـه

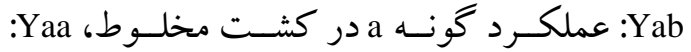

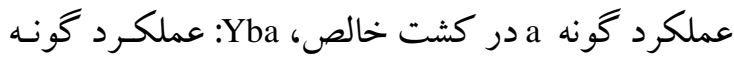

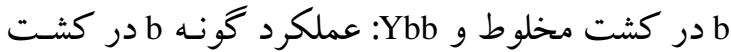
خالص هستند (Shakiba et al., 2016). دادههاى دو ساله آزمايش به صورت مركب تجزيسه

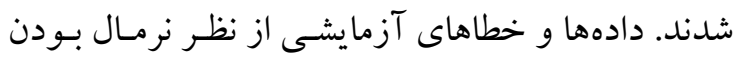

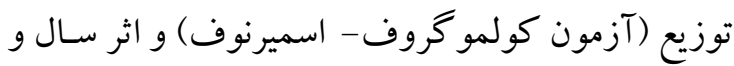
تيمارهاى آزمايشى براى همسـانى واريـانس هـا (آزمـون

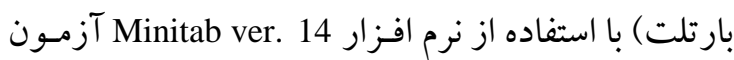
شدند. تجزيه واريـانس دادههـا بـا استفاده از نـرم افززار SAS

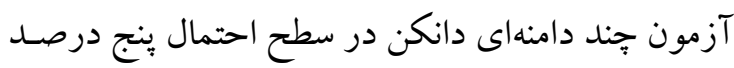

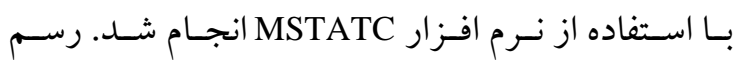

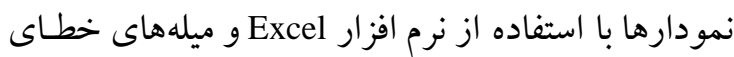
آزمايشى (Error bars) بر اساس انحراف معيار رسم شد.

\section{نتايج و بحث}

نتايج تجزيه واريـانس مركب دادههـا نشـان داد كـه اثر سال، نسبتهاى مخلوط، كود و جين بر وزن خشك لهر

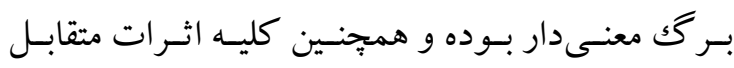

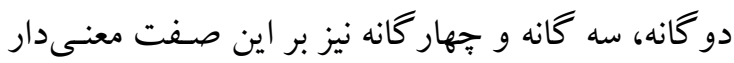

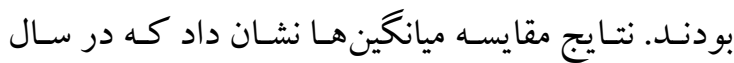

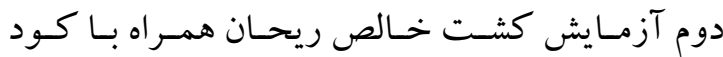
شـيميايى نيتـروزن در جـين دوم، بيشـترين ميـزان وزن

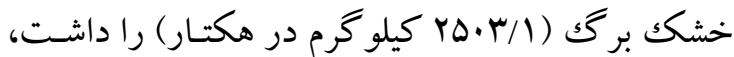
هر جند اين مقدار با وزن خشك بـر گك بـدست آمـده در كشت خالص ريحان و مصـرف تلفيقى •ه درصد كود شيميايى نيتروزن همر اه با نيترو كسين در جـين دوم

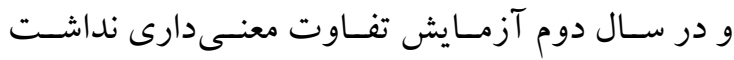

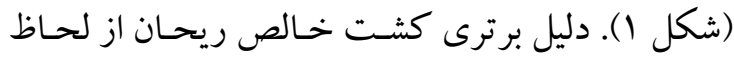

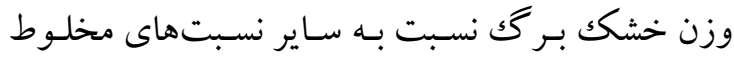

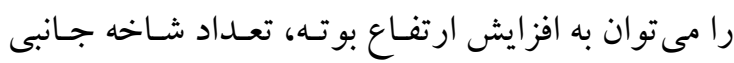

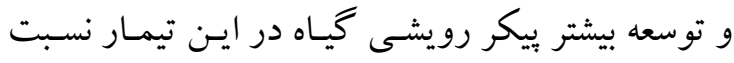

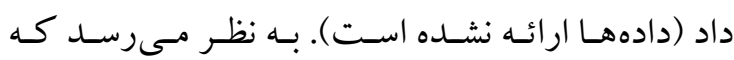




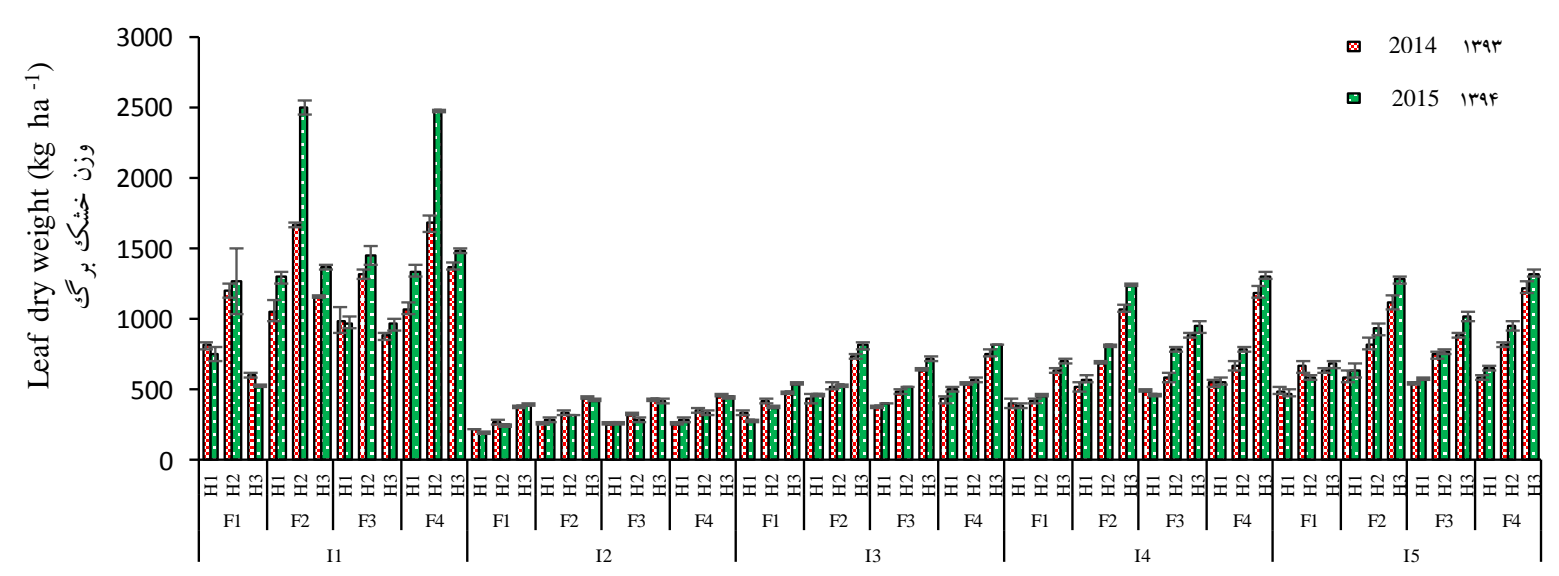

شكل 1- مقايسه ميانكين وزن خشك برگك ريحان در برهمكنش نسبتهاى مخلوط با ذرت و منابع كود نيتروزن در

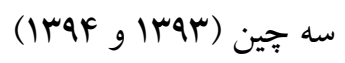

Fig. 1. Mean comparisons of leaf dry weight of sweet basil in interaction effect of intercropping ratios with maize and nitrogen fertilizer sources in three cuts (2014 and 2015)

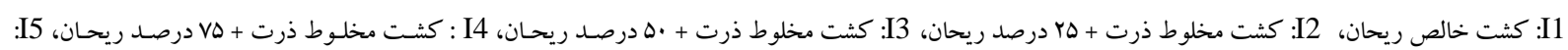

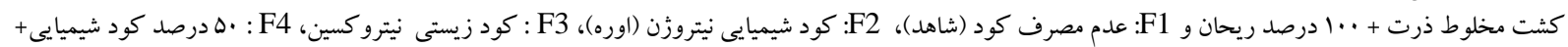

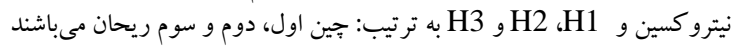

I1, I2, I3, I4 and I5: sole cropping of sweet basil, intercropping of maize + 25\% sweet basil, maize + 50\% sweet basil, maize $+75 \%$ sweet basil and maize $+100 \%$ sweet basil, respectively. F1: without fertilizer (control), F2: nitrogen chemical fertilizer (urea), F3: bio-fertilizer (Nitroxin), F4: 50\% nitrogen chemical fertilizer + Nitroxin and H1, H2 and H3: first, second and third cuts of sweet basil, respectively

بوتههـاى ريحـان وزن خشـك ريحـان در واحـد سـح

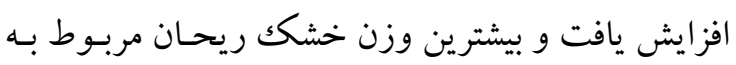

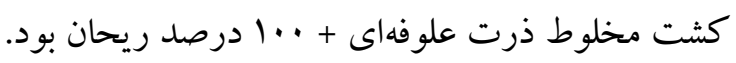

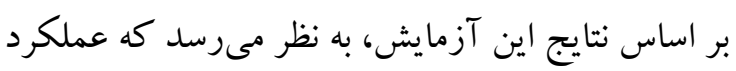

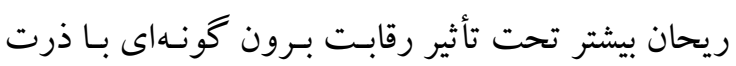
قرار كرفتـه و رقابـت درون گونسهاى تـأثير كمتـرى بـر

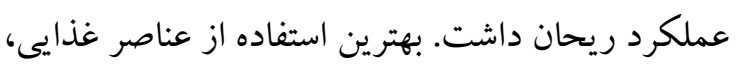

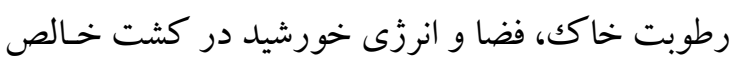

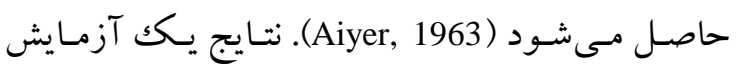
نشان داد كه وزن خشك كل ريحان در كشـت خـالص نسبت به تيمارهاى كشت مخلوط ذرت و ريحـان بيشتر

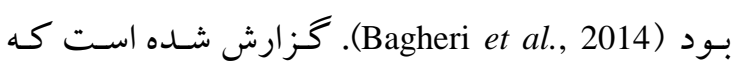
رقابت بين گونهاى براى نور و نيتروزن در طول دوره

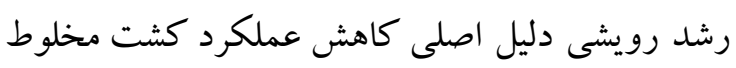
نسبت بـه كشت خالص است (Thorsted et al., 2006).

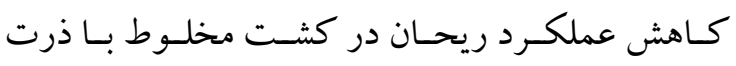

$$
\begin{aligned}
& \text { وزن خشك كياه ريحان به طور معنىدارى تحـت تـأثير }
\end{aligned}
$$

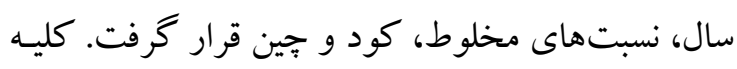

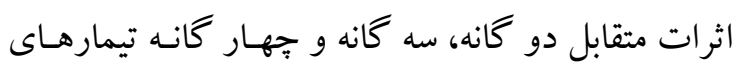

$$
\begin{aligned}
& \text { آزمايش بجز برهمكنش سال × كود × جين نيـز بـ بر ايسن }
\end{aligned}
$$

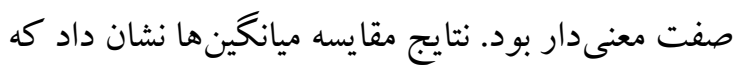

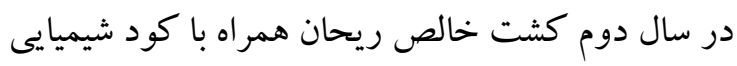

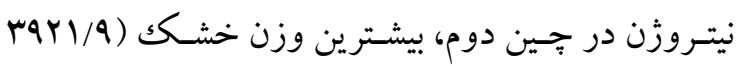

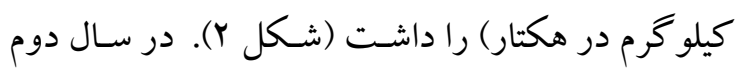

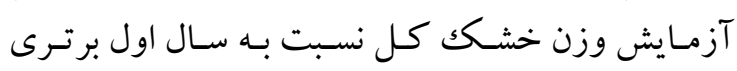

$$
\begin{aligned}
& \text { محسو سسى داشـت. علـت ايسن موضسوع را مسى تـوان بـهـ } \\
& \text { مســاعد بــودن شـــرايط آب و هـــوايى در ســـال دوم }
\end{aligned}
$$

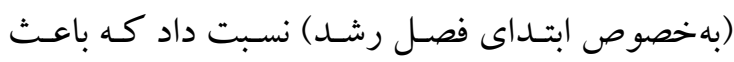

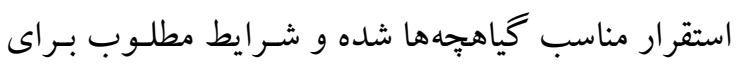

$$
\begin{aligned}
& \text { توليد عملكرد بالا فراهم گرديد. }
\end{aligned}
$$

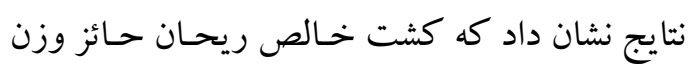
خشك بالاترى بود. در كشت مخلوط، با افزايش تراكم 
" اثر منبع كود نيتروزن بر عملكرد...، يناهيان گيوى و همكاران،

مهمى كـه در افززايش رشـد رويشـى كيـاه دارد، باعـث

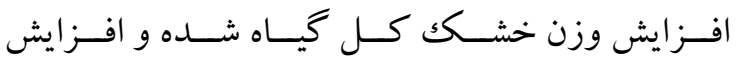

مصــرف نيتـــروزن از طريــق تــأثير بـــر فر آينـــدهاى وره

فيزيولوزيكى، باعث افزايش فتوسنتز، توليد مواد برورده

و مـاده خشـكك و عملكــــد بـالاتر مسى شـود. افـزايش

عملكرد ريحان در تيمار كود زيستى نيترو كسـين نسـبت

به شاهد را مى توان به نقش ازتوباكتر و آزوسـيير يلوم در

تثيت نيتروزن و توليد مواد محر كك رشد مانتـد جيبـرلين

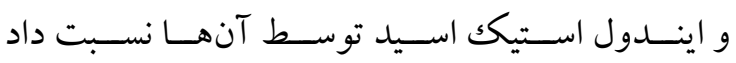

(Mahfouz and Sharaf-Eldin, 2007)

كليـه جــين هـاى ريحــان در مرحلـهى رشـــى يكسـان

برداشت شدند، به نظر مىرسد كه جـين اول كـه مواجـهـ
مى تواند به اين دليل باشـد كـه ذرت در كشـت مخلـوط بـا كياهـانى كـه نسـبت بــه آن ارتفـاع كمتـرى دارنسل،

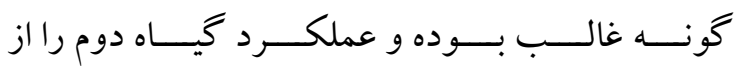
طريق سـايهاندازى تحـت تـأثير قـرار مسىدهـد. كـاهش

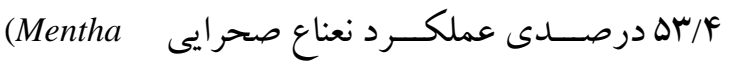
arvensis L.f. piperascens Malinv. ex Holme) در كشت مخلوط با شمعدانى معطر (Pelargonium sp)، در مقايسه با كشت خالص، كزارش شده است r Rajeswara Rao, 2002) مشاهده مىشود تيمار هاى نيتروزن نسبت بـه تيمـار عـدم مصرف كود، باعث افزايش وزن خشك ريحان در كليه نسبت هاى كشت مخلوط كرديد. نيتروزن به دليل نقـش

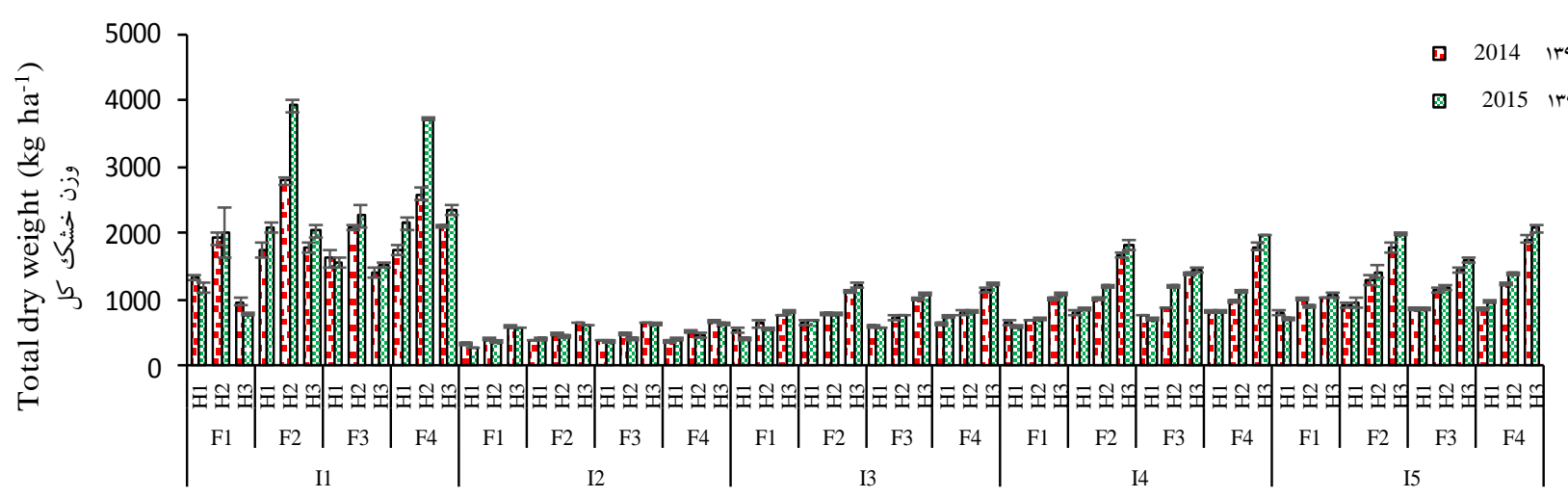

شكل Y - مقايسه ميانكين وزن خشك كل ريحان در برهمكنش نسبت هاى مخلوط با ذرت و منابع كود نيتروزن

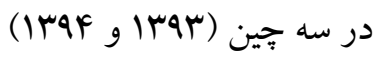

Fig. 2. Mean comparisons of total dry weight of sweet basil in interaction effect of intercropping ratios with maize and nitrogen fertilizer sources in three cuts (2014 and 2015)

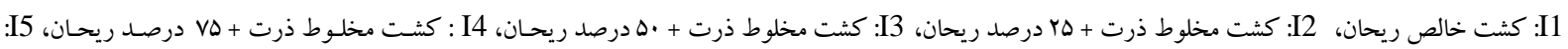

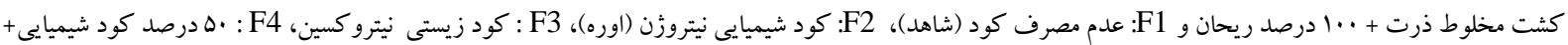

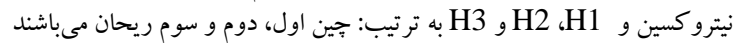

I1, I2, I3, I4 and I5: sole cropping of sweet basil, intercropping of maize + 25\% sweet basil, maize + 50\% sweet basil, maize $+75 \%$ sweet basil and maize $+100 \%$ sweet basil, respectively. F1: without fertilizer (control), F2: nitrogen chemical fertilizer (urea), F3: bio-fertilizer (Nitroxin), F4: 50\% nitrogen chemical fertilizer + Nitroxin and H1, H2 and H3: first, second and third cuts of sweet basil, respectively

بـــــود. از سوى ديكر در جــــــــن اول ريحان مقدارى از انرزى كيــاه براى استقرار صرف شــــ، در حالى كه در بازرويش يس از جهـين اول، بخشى از مسير رشدى كيـاه

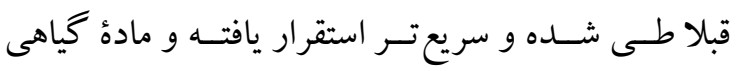

با دماى بالاتر هو ا بوده، سريع تـر وارد مرحله كَلدهـى شده است، از اين رو با توليد بوتهايى با ارتفاع و تعـداد ساقه فرعى كمتر و در نتيجه رشد رويشسى كمتـر، داراى عملكرد زيستى كمترى نسبت به جـين هـاى دوم و سـوم 


$$
\text { "نشريه علوم زراعى ايران"، جلد بيست و يكم، شماره با، باييز هوبا }
$$

جانبى و ارتفاع بو ته گ گرديد (دادهها ارائه نشده است). بـا

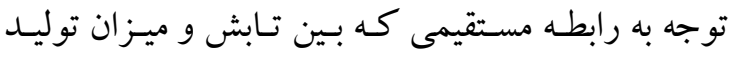

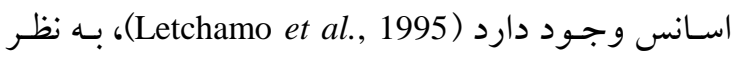

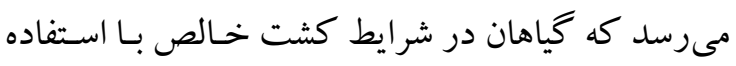

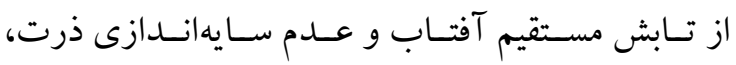
بيشترين ميزان اسانس را توليد كردند.

ميزان اسانس ريحان در تيمارهاى نيترو كسين و عدم

مصـرف كـود نسـبت بـه تيمـار كـود شـيميايى و تيمـار

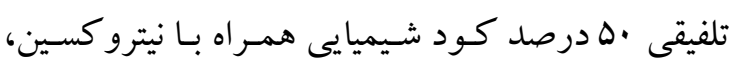

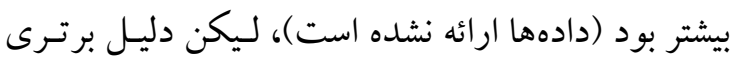

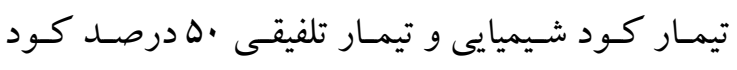

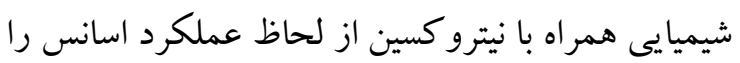
مى توان اين گونه توجيه كرد كه عملكـرد اسـانس بيشـتر

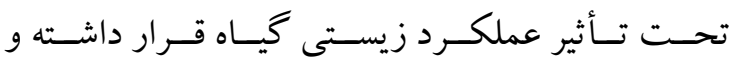

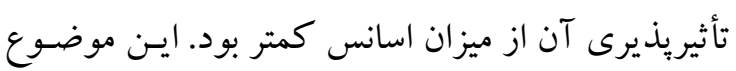

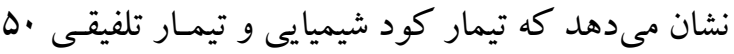

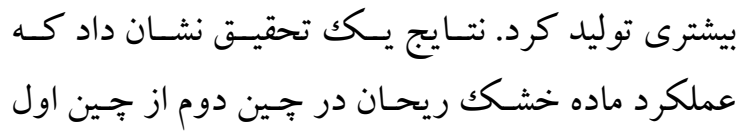

بيشتر بود (Rezaei Moadab, 2014). نتايج تجزيه واريانس مر كب دادهها نشان داد كه اثر

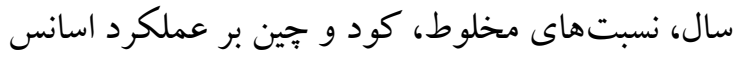

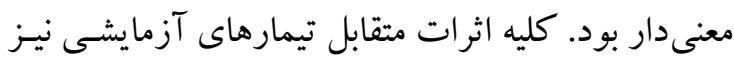
بر اين صفت معنى دار بود. نتايج مقايسه ميانگينها نشـان

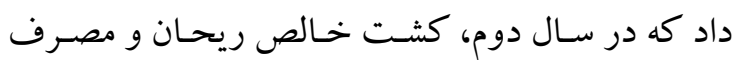

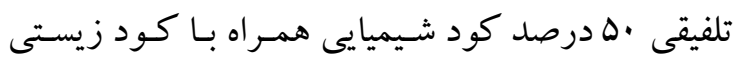

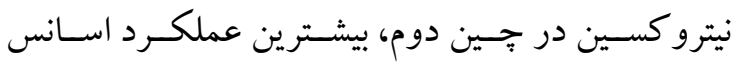

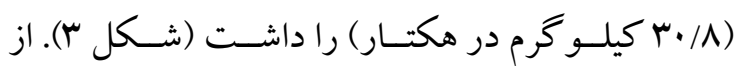
دلايل برترى كشـت خـالص ريحـان از لحـاظ عملكـرد درد

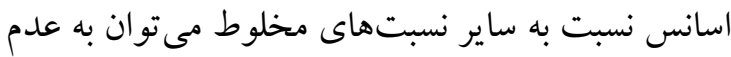

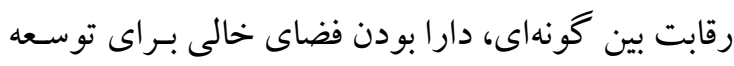

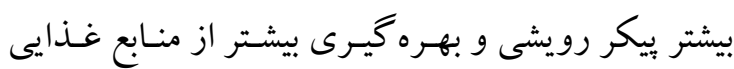

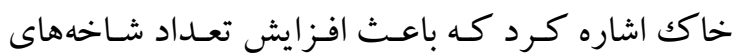

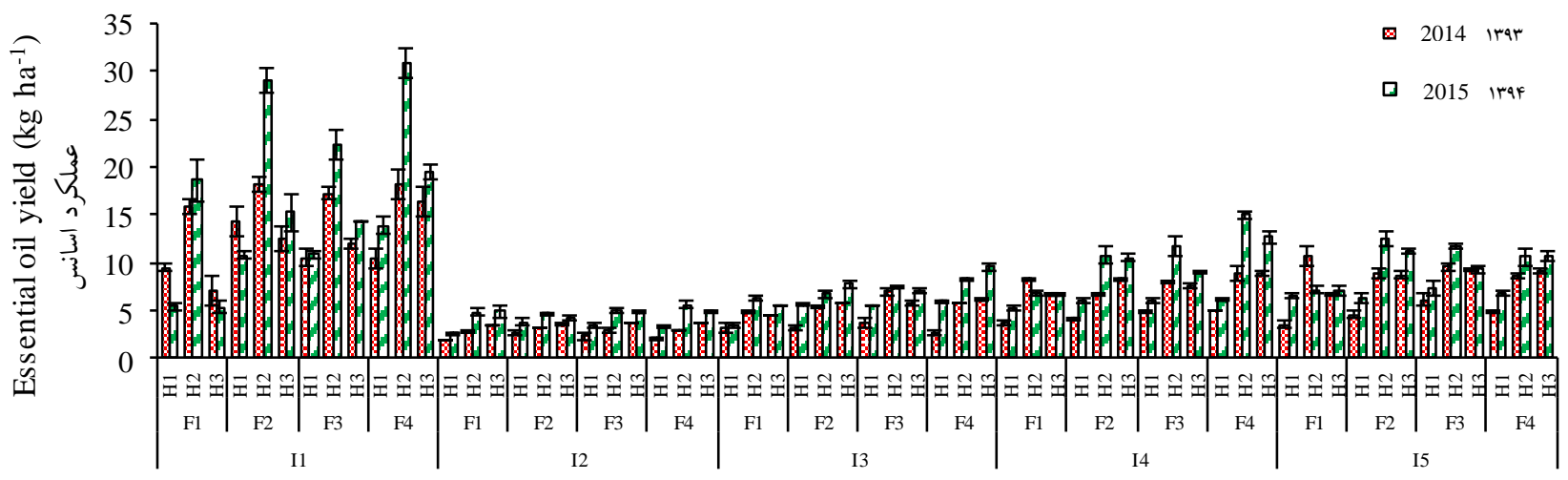

$$
\begin{aligned}
& \text { شكل r- مقايسه ميانگين عملكرد اسانس ريحان در برهمكنش نسبتهاى مخلوط با ذرت و منابع كود نيتروزن در سه }
\end{aligned}
$$

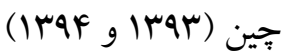

Fig. 3. Mean comparisons of essential oil yield of sweet basil in interaction effect of intercropping ratios with maize and nitrogen fertilizer sources in three cuts (2014 and 2015)

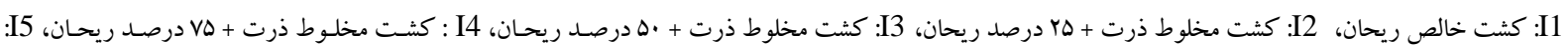

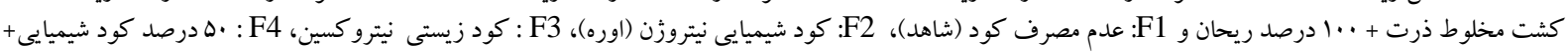

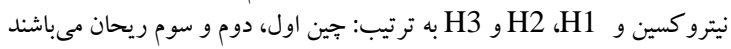

I1, I2, I3, I4 and I5: sole cropping of sweet basil, intercropping of maize + 25\% sweet basil, maize + 50\% sweet basil, maize $+75 \%$ sweet basil and maize $+100 \%$ sweet basil, respectively. F1: without fertilizer (control), F2: nitrogen chemical fertilizer (urea), F3: bio-fertilizer (Nitroxin), F4: 50\% nitrogen chemical fertilizer + Nitroxin and H1, H2 and H3: first, second and third cuts of sweet basil, respectively 
تسوجهى بـا تيمـار كـود شـيميايى نداشـته و از عملكـــد بالايى برخوردار بود (جـدول Y). بـه نظـر مسرسـد كـه

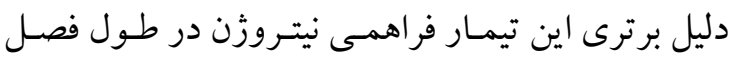

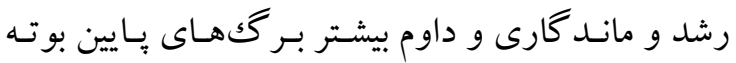

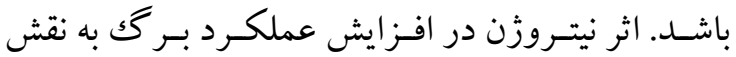

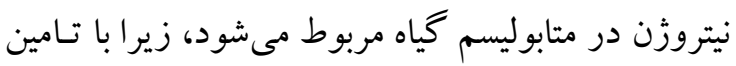

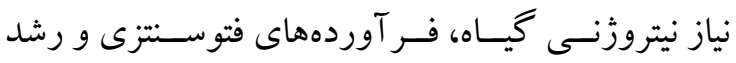

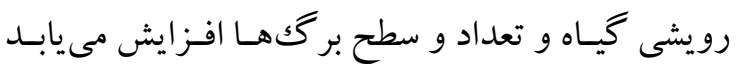

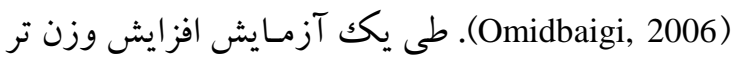

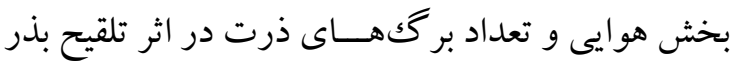

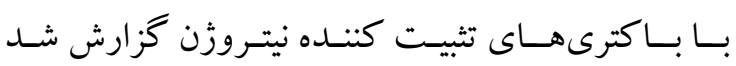

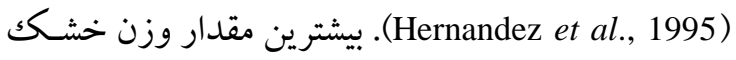

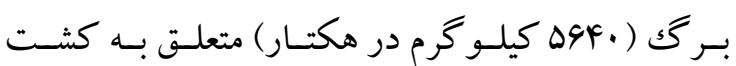

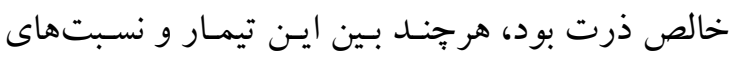

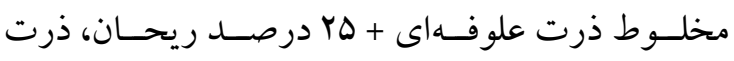

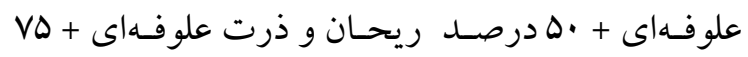
درصد ريحان تفاوت معنى دارى وجود نداشت (جـدول

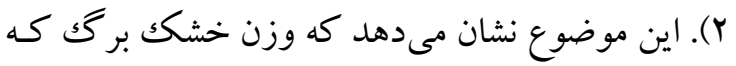

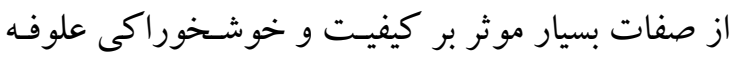

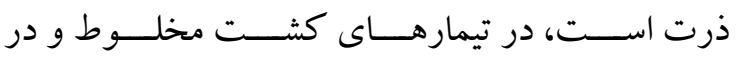

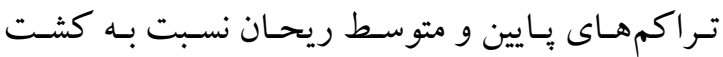

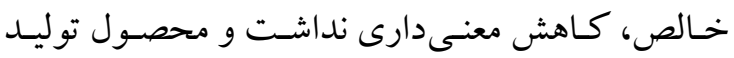

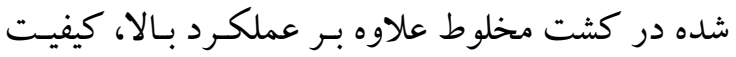

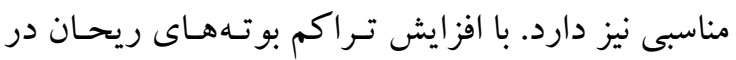
تيمار ذرت علوفهاى + +.

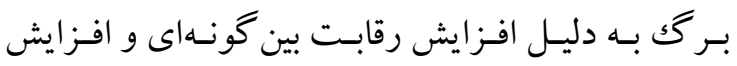

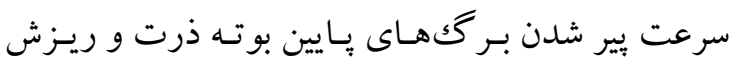

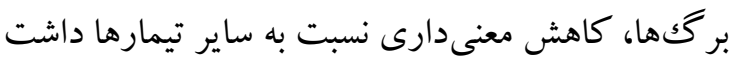

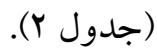

نتـايج تجزيـهـ واريـانس نشــان داد كـهـ اثــــــــال، نسبت هاى مخلوط و كود بر وزن خشكك بـلال معنى دار

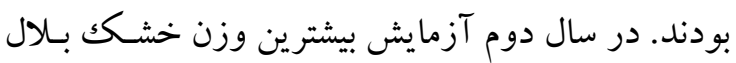

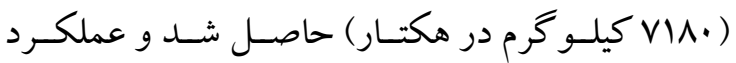

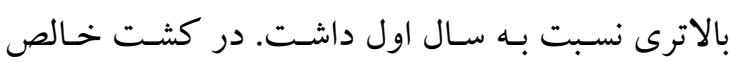

درصد كود شيميايى همر اه با نيترو كسين، بيشتر از طريق

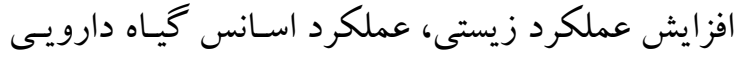
ريحان را تحت تأثير قرار مىدهند. نتايج يـك لمك آزمايش

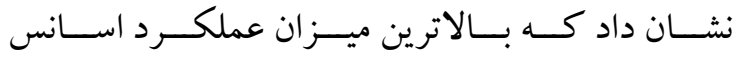
كيـاه دارويسى رازيانه (Foeniculum vulgare Mill) در

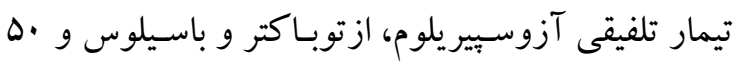

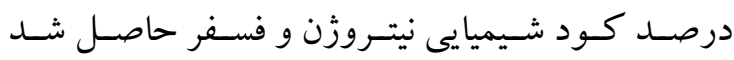
(Mahfouz and Sharaf-Eldin, 2007) در جين دوم عملكرد زيستى و درصــ اسـانس بيشـتر از

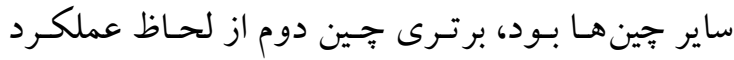
اسانس قابل انتظار بود. نتايج يكك تحقيق نشان داد كه از

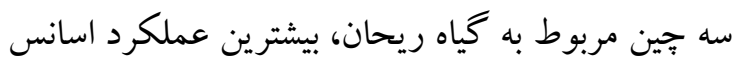

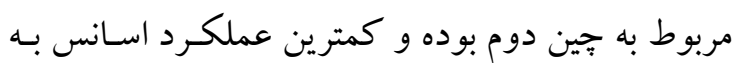

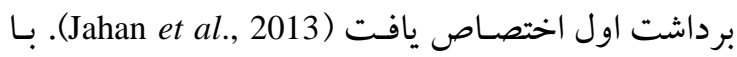
توجه به اينكه عملكرد اسانس رابطه مستقيمى با عملكرد

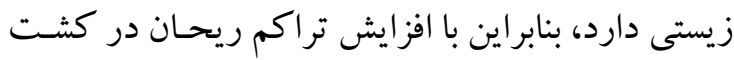

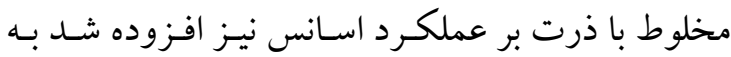
طورى كه در بين نسـبتهاى كشـت مخلـوط، بيشـترين

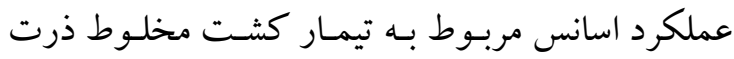

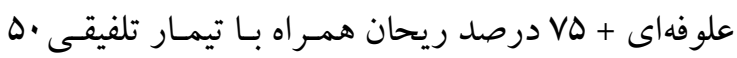
درصد كود شيميايى همراه بـا كـود زيستى نيترو كسـين

نتايج حاصل از تجزيه واريانس مر كب دادهها نشـان داد كه نسبتهاى مخلوط و كود اثر معنىدارى بـر وزن

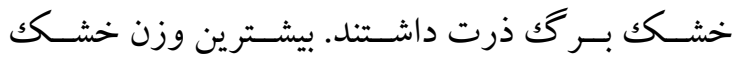

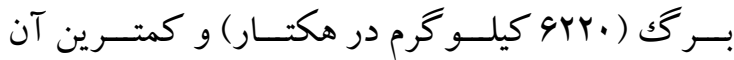

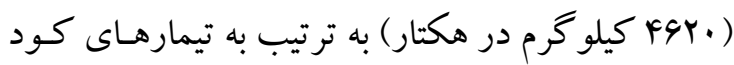

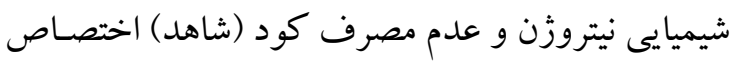
داشتند (جدول Y). اين موضوع مى تو اند بـه دليـل تـاثير

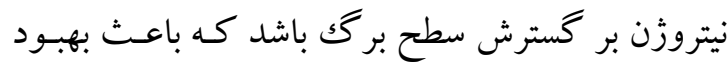

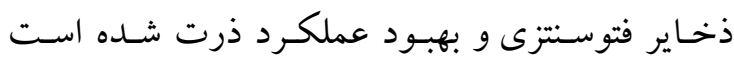

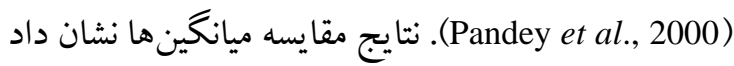
كه تيمار تلفيقى •ه درصد كود شيميايى نيتروزن همـر اه

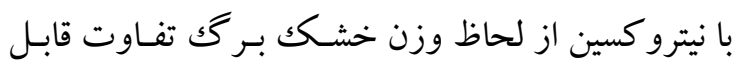




$$
\text { "نشريه علوم زراعى ايران"، جلد بيست و يكم، شماره با، باييز شهسا }
$$

باعث افزايش فاصله زمانى بين آزاد شدن دانه كرده و ظهور كاكل ها مسىشـود، بـه نظـر مسىرسـد كـه يكى از عو امل اصلى كاهش وزن بـلال و عملكرد دانه در تيمـار شـاهد (عــدم مصـرف كــود)، عدم همز مانى بين كرده افشانى و ظهور كاكل ها باشد كه باعـث عقيمسى و عـدم بارورى بلال مى كردد.

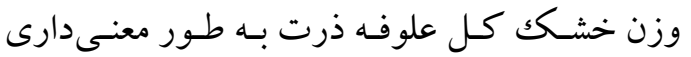
تحت تاثير سال، نسبتهاى مخلوط و كود قرار گرفت. مقايسه ميانكين ها نشـان داد كـه وزن خشـك علوفـه در سال دوم ( •ها191 كيلو گرم در هكتـار) نسـبت بـه سـال اول ( IVV9 كيلو گرم در هكتار) بيشتر بـود. علـت ايسن موضوع را مىتوان به مساعد بودن شرايط آب و هـوايى به خصوص در ابتداى فصل رشد در سال دوم نسبت داد كه باعث سبز شدن يكنواخت و استقرار مناسـب بوتسهها شده و شرايط مطلوب بر ای توليـد عملكـرد بـالا فـراهم

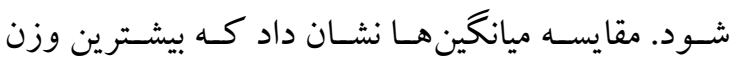

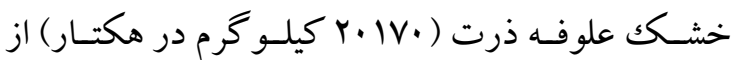
تيمار كـود شـيميايى نيتـروزن بدسـت آمـد (جـدول Y). افزايش r ا درصدى علوفه خشكك ذرت در تيمـار كـود
ذرت بيشـترين وزن خشـك بـالال ( • ا9 كيلـو كرم در هكتار) بدست آمد كه نسبت به تيمارهاى مخلـوط برتـر بود (جدول Y). به نظر مىرسد با وجود اينكه در كشـت مخلوط ذرت و ريحان، ذرت كياه غالب مسىباشـد و در رقابت بر سر منابع خاكك و تـابش، گونسه برتر بـود، امـا حضور ريحان در كشت مخلوط با ذرت باعث مسىشود

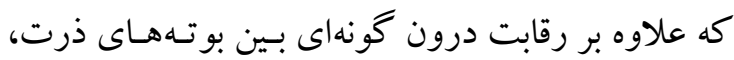
رقابـت بـين كونسهاى نيـز اتفــاق افتـاده و باعـث كـاهش عملكرد ذرت شود. گزارش شد كه در كشـت مخلـوط ذرت و ريحان وزن خشك بلال در كشت خالص بيشتر از مخلــوط بــود (Bagheri et al., 2014). بيشــرين و كمترين وزن خشكك بـالال در بـين تيمارهـاى كـودى به ترتيب مربـوط بـه تيمارهـاى كـود شـيميايى نيتـروزن ( S VYG. ) (

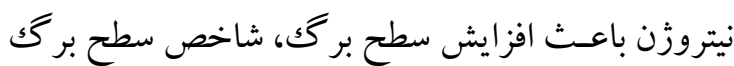

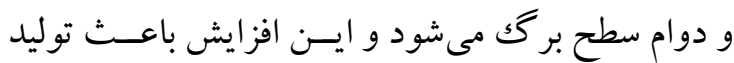

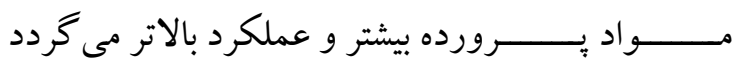
(Malakouti, 1998)

جدول - مقايسه ميانگين صفات گياهى ذرت علوفهاى در تيمارهاى كشت مخلوط با ريحان و منابع كود نيتروزن (Iraf, grar)

Table 2. Mean comparison of plant characteristics of maize in intercropping ratios with sweet basil and

\begin{tabular}{|c|c|c|c|c|}
\hline $\begin{array}{c}\text { يمارهاى آزمايشى } \\
\text { Treatments } \\
\end{array}$ & & $\begin{array}{c}\text { وزن خشك بركى } \begin{array}{c}\text { Leaf dry weight } \\
\left(\mathrm{kg} \cdot \mathrm{ha}^{-1}\right)\end{array} \\
\end{array}$ & $\begin{array}{c}\text { وزن خشك بلال } \begin{array}{c}\text { ونar dry weight } \\
\left(\mathrm{kg} \cdot \mathrm{ha}^{-1}\right)\end{array} \\
\end{array}$ & $\begin{array}{c}\text { وزن خشك كل } \begin{array}{c}\text { Thal dry weight } \\
\left(\mathrm{kg} \mathrm{ha}^{-1}\right)\end{array} \\
\end{array}$ \\
\hline 2014 & irar & $5290 \mathrm{a}$ & $6580 \mathrm{~b}$ & $17760 \mathrm{~b}$ \\
\hline 2015 & iraf & $5.610 \mathrm{a}$ & $7180 \mathrm{a}$ & $19150 \mathrm{a}$ \\
\hline Sole cropping of maize & كثت خالص ذرت & $5640 \mathrm{a}$ & $7190 \mathrm{a}$ & $19220 \mathrm{a}$ \\
\hline Maize $+25 \%$ sweet basil & ذرت + ذا درصد ريحان & $5630 \mathrm{a}$ & 7030ab & 19000ab \\
\hline Maize $+50 \%$ sweet basil & ذرت + •هدرصد ريحان & $5490 \mathrm{a}$ & $7000 \mathrm{~b}$ & $18690 \mathrm{~b}$ \\
\hline Maize $+75 \%$ sweet basil & 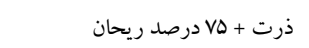 & $5390 \mathrm{a}$ & $6760 \mathrm{c}$ & $18170 \mathrm{c}$ \\
\hline Maize $+100 \%$ sweet basil & ذرت + +. إدرصد ريحان & $5100 \mathrm{~b}$ & $6430 \mathrm{~d}$ & $17190 \mathrm{~d}$ \\
\hline Control & شاهد (عدم مصرف كود) & $4620 d$ & $6190 \mathrm{c}$ & $16100 d$ \\
\hline $100 \%$ chemical fertilizer (urea) & كود شيميايى نيتروزن (اوره) & $6220 \mathrm{a}$ & $7260 \mathrm{a}$ & 20170a \\
\hline Biofertilizer (Nitroxin) & كود زيستى (نيترو كسين) & $4990 \mathrm{c}$ & $6990 \mathrm{~b}$ & $17960 \mathrm{c}$ \\
\hline Biofertilizer $+50 \%$ chemical fertilizer & كود زيستى +هادرصد كود شيد & $5980 \mathrm{~b}$ & $7080 \mathrm{~b}$ & $19590 \mathrm{~b}$ \\
\hline
\end{tabular}

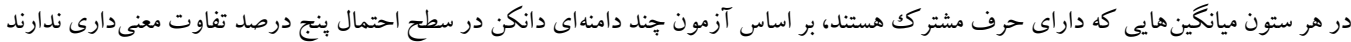
Means in each column followed by similar letter(s) are not significantly different at 5\% probability level, using Duncan's Multiple Range Test 
" اثر منبع كود نيتروزن بر عملكرد...، يناهيان گيوى و همكاران،

جدول س- نسبت برابرى زمين در تيمارهاى كشت مخلوط ذرت و ريحان و منابع كود نيتروزن (سوس و و I I )

Table 3. Land equivalent ratio (LER) in intercropping treatments of maize with sweet basil and nitrogen fertilizer sources (2014 and 2015)

\begin{tabular}{|c|c|c|c|}
\hline $\begin{array}{c}\text { تيمارهاى آزمايشى } \\
\text { Treatments }\end{array}$ & & $\begin{array}{r}1 r a r \\
2014 \\
\end{array}$ & $\begin{array}{l}\text { Iraf } \\
2015 \\
\end{array}$ \\
\hline Maize $+25 \%$ sweet basil-without fertilizer & ذرت + T T درصد ريحان-عدم مصرف كود & 1.28 & 1.29 \\
\hline Maize $+25 \%$ sweet basil+chemical fertilizer & ذرت + † د درصد ريحان+ كود شيميايى نيتروزن & 1.22 & 1.17 \\
\hline Maize $+25 \%$ sweet basil+biofertilizer & ذرت + ذه درصد ريحان+ كود زيستى & 1.31 & 1.23 \\
\hline Maize $+25 \%$ sweet basil + biofertilizer $+50 \%$ chemical fertilizer & ذرت + هr درصد ريحان+ •ه درصد كود شيميايى + كود زيستى & 1.25 & 1.16 \\
\hline Maize $+50 \%$ sweet basil-without fertilizer & ذرت + •هدرصد ريحان- عدم مصرف كود & 1.38 & 1.38 \\
\hline Maize $+50 \%$ sweet basil + chemical fertilizer & ذرت + •هدرصد ريحان+ كود شيميايى نيتروزن & 1.34 & 1.33 \\
\hline Maize $+50 \%$ sweet basil + biofertilizer & ذرت + •هدرصد ريحان+كود زيستى & 1.46 & 1.41 \\
\hline Maize $+50 \%$ sweet basil + biofertilizer $+50 \%$ chemical fertilizer & ذرت + •ه درصد ريحان+ •ه درصد كود شيميايى + كود زيستى & 1.38 & 1.33 \\
\hline Maize $+75 \%$ sweet basil and control & ذرت + VD درصد ريحان- عدم مصرف كود & 1.46 & 1.52 \\
\hline Maize $+75 \%$ sweet basil + chemical fertilizer & ذرت + VD درصد ريحان+ كود شيميايى نيتروزن & 1.45 & 1.43 \\
\hline Maize $+75 \%$ sweet basil + biofertilizer & ذرت + ل v درصد ريحان+ كود زيستى & 1.55 & 1.54 \\
\hline Maize $+75 \%$ sweet basil + biofertilizer $+50 \%$ chemical fertilizer & ذرت + Vه درصد ريحان+ •ه درصد كود شيميايى + كود زيستى & 1.49 & 1.46 \\
\hline Maize $+100 \%$ sweet basil-without fertilizer & ذرت + .. ادرصد ريحان-عدم مصرف كود & 1.54 & 1.52 \\
\hline Maize $+100 \%$ sweet basil + chemical fertilizer & ذرت + . ادرصد ريحان+ كود شيميايى نيتروزن & 1.51 & 1.47 \\
\hline Maize $+100 \%$ sweet basil + biofertilizer & ذرت + .. ادرصد ريحان+كود زيستى & 1.56 & 1.56 \\
\hline Maize $+100 \%$ sweet basil + biofertilizer $+50 \%$ chemical fertilizer & ذرت + ·. ادرصد ريحان+ •هدرصد كود ش & 1.52 & 1.48 \\
\hline
\end{tabular}

كاهش عملكـــرد زيسـتى ذرت همزمان با افزايش سهم كدو در كشــت مخلوط در تيمارهــــاى آلوده به تـــاج خـــروس (Amaranthus retroflexus L)، بنــدانـــهـ و ســاير علـف هــاى هــرز (Hyoscyamus niger L) كـز ارش شــده اسـت (Ghanbari et al., 2010). در

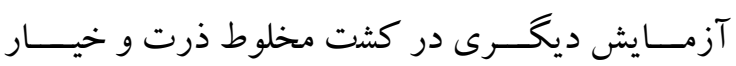
(Cucumis sativus L.) همز مـان بـا افزايش ســهم خيــار در مخلــوط كزارش شده است (Ghanbari et al., 2006). نتايج نشان داد كه در هر دو سال آزمـايش، بيشترين نسبت برابرى زمين (LER) وها بود كه در تيمار كشت مخلـوط ذرت علوفـهاى + + · إدرصـد ريحسان همـرا با كود زيستسى نيترو كسـين بـهدسـت آمــ. كمترين ميزان نسبت برابرى زمين در سـال اول rY / بـود كه در تيمـار كشت مخلوط ذرت علوفهاى + Dا درصد ريحان همراه با كود شيميايى و در سال دوم در تيمار كشـت مخلـوط ذرت علوفـهاى + Q Y درصـد ريحــان همـر اه با مصـرف تلفيقى كود بهدست آمد (جدول س). در كليـه تيمارهـاى كشـت مخلوط نسبت برابرى زمين بيشتر از يكك بـود كه
زيستى نيترو كسين نسبت به شاهد را مسىتـوان بـه اثـرات مفيد باكترىها در تثبيت نيتروزن و همجينين ترشح مـواد تنظيم كننده و تحريكك كننده رشد توسط ايسن باكتريها

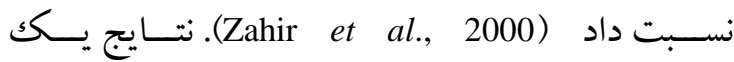

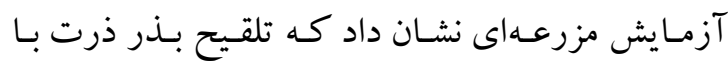
بـاكترىهـاى تثيـت كنتـده نيتـروزن، باعـث افـزايش عملكـرد علوفه تـر در تيمارهـاى برخـوردار از كـود نيتروزن شد (Nanda et al., 1995). نتـايج نشـان داد كـه لـ

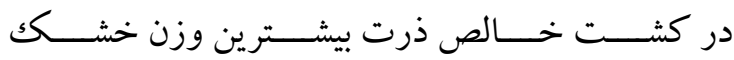

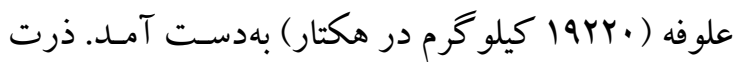
در كشت مخلوط بـا كياهـانى كـه نسـبت بـه آن ارتفـاع بوته كمترى دارند، گونه غالب بوده و عملكرد آن كمتر

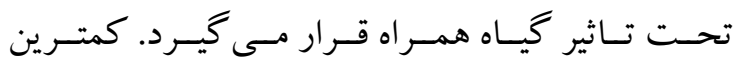
وزن خشك علوفه ( . IVI9 كيلو گرم در هكتـار) متعلسق به كشت مخلوط ذرت علوفـهاى + + . ا درصـد ريحـان

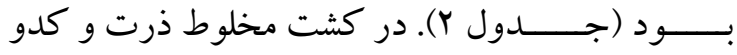
نيز بيشـترين عملكـرد زيستى ذرت در (Cucurbita sp.) تيمار كشت خالص ذرت بدون علف هرز و بس از آن در كشت خالص ذرت بدون وجين بدست آمد. بعلاوه 


$$
\text { "نشريه علوم زراعى ايران"، جلد بيست و يكم، شماره با، باييز شجسا }
$$

ديخر نشـان داد كه كليه تيمارهاى كشت مخلوط جـو و ماشـك كـل خوشـهاى LER بـالاترى نسبت به كشت خالص دو كيـاه داشتند. بـه نظـر مسىرسـد كـه يكى از دلايل موفقيت آميز بودن كشت مخلـوط ايسن دو كيـاه، تثيت زيستى نيتروزن توسط ماشكك كل خوشهاى و اثر مساعدتى آن در كشت مخلوط باشد (Ahmadi, 2010).

\section{نتيجه كيرى}

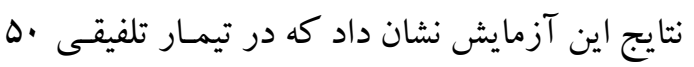
درصد كود شيميايى + كود زيستى نيترو كسين در هر دو كياه ذرت و ريحان، عملكرد كل قابـل تـوجهى بدسـت آمد و عملكرد اسانس ريحان نيز در اين تيمار نسـبت بـه تيمار كـود شـيميايى برتـرى داشـت، بنـابراين مسى تـوان استفاده تلفيقى از كود زيستى نيترو كسين + •له درصــ كود شيميايى اوره را به عنوان راهكارى جهـت كـاهش له مصـرف كودهــاى شـيميايى و در راسـتاى كشـاورزى بايدار مورد توجه قرار داد. نتايج اين بـزّوهش نشـان داد

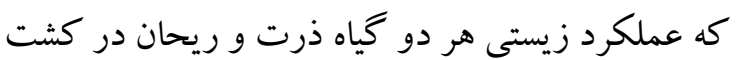
خالص نسبت به تيمارهاى كشـت مخلـوط برتـر بـود، بـا

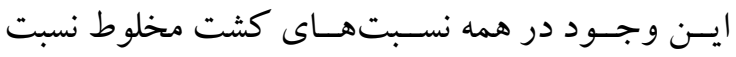
برابرى زمين بيشتر از يكك بــود كه نشان دهنده بر تــــى

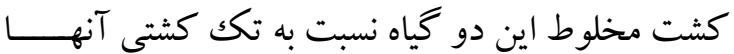
مىباشد. به نظر مىرسد كه به دليل حجم شاخساره نسبتاً يـايين كيـاه ريحـان، هـر جـهـ تـراكم ريحـان در كشـت مخلـوط افزايشـى بــا ذرت افـزايش داده شـود، اهـــاف

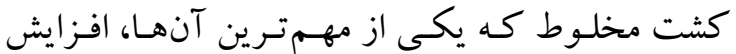
عملكرد اقتصادى هـر دو گيـاه مسىباشـد، بيشـتر محقـق مى شود.
نشان دهنده كارايى كشت مخلوط اين دو كياه نسبت به تكك كشتى مىباشد. ارزيابى نسبت هاى كشـت مخلـوط ذرت و ريحان نشان داد كه نسبت برابرى زمين در سـال اول بين r/1/ و 1/09 و در سـال دوم بسين 1/19 و 1/09 بود، يعنى سودمندى استفاده از زمين در كشـت مخلـوط به ترتيب در سال اول r Y و وه درصـد و سـال دوم 19 و وه بيشتر از كشت خالص بـود. جداسـازى آشـيانهـاى

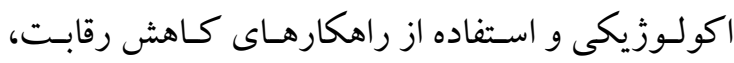
مى تواند توضيحى براى سودمندى كشت مخلـوط ذرت و ريحان نسبت به كشت خالص آنهـا باشـد. در كشـت مخلوط سطح بركى در واحد سطح افزايش مىيابـد كـه

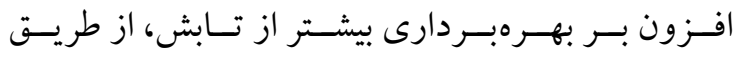
سايهاندازى، دماى خاكك و به دنبـال آن تبخيـر كـاهش مى يابد و بدين ترتيب تابش و آبى كه در كشت خـالص به هدر مىرود، وارد جرحخه توليد مىشود. در خاكك نيـز تفاوتهاى مورفولوزيكى ريشه، باعث بهرهبردارى بهتـر و بيشتر از عناصر غـذايى در افـقهـاى خـاكك مسى شـود. افزايش زيست توده ريشه در خاكك و ترشح برخى مواد آلى از ريشـهـهـا در ريزوسـفر مى توانـد باعـث افـزايش فعاليتهاى ميكروار گانيسمهاى مفيد خاكك شـود. نتايج حاصل از اين بززوهش نشان داد كه نســبت هاى كشــت مخلوط همر اه بـا كـود زيسـتى، LER بـالاترى نسبت به به ســـــاير تيمارها داشــــت كه نشان دهنده كارايـى بالاى كودهاى زيستـى نسبت به كودهاى شيميايى مسىباشـــ. در آزمايشى با ارزيابى اثر كودهاى زيستى و شيميايى بر كشت مخلوط زنيـان و شــبليله نتـايج مشـابهى كَزارش

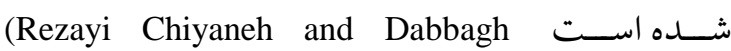
Mohammadi Nassab, 2014)

\section{References}

منابع مورد استفاده

Abedi, M. H., M. J. Seghatoleslami and S. G. R. Mousavi. 2014. Effects of irrigation intervals and nitrogen fertilizer levels on vegetative and reproductive yields of basil (Ocimum basilicum L.) under Birjand conditions. J. Agroecol. 5(4): 342-349. (In Persian with English abstract).

Ahmadi, A., A. Dabagh mohammadi Nasab, S. Zehtab Salmasi, R. Amini and H. Janmohammadi. 2010. 


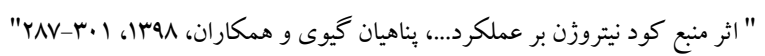

Evaluation of yield and advantage indices in barley and vetch intercropping. J. Agric. Sci. Sustain. Prod. 20: 77-87. (In Persian with English abstract).

Aiyer, A. K. 1963. Principles of Crop Husbandry in India. Bangalore Press, Bangalore, India.

Alexandratos, N. 2003. World agriculture: towards 2015-30. In Proceeding of Congress on Global Food Security and Role of Sustainable Fertilization, 26-28 March 2003. Rome. Italy.

Bagheri, M., F. Zaefarian, B. Bicharanlou and H. Ghanizadeh. 2014. A Study of intercropping ofmMaize with sweet basil and borage. Cercet. Agron. Mold. 47: 13-28.

Chen, X., Z. Cui, M. Fan, R. Vitousek, M. Zhao, W. Ma, Z. Wang, W. Zhang, X. Yan, J. Yang, X. Deng, Q. Gao, Q. Zhang, S. Guo, J. Ren, S. Li, Y. Ye, Z. Wang, J. Huang, Q. Tang, Y. Sun, X. Peng, J. Zhang, M. He, Y. Zhu, J. Xue, G. Wang, L. Wu, N. An, L. Wu, L. Ma, W. Zhang and F. Zhang. 2014. Producing more grain with lower environmental costs. Nature. 514: 486-489.

Ghalichi Sofla, M., S. Seifzadeh and M. Khodadadi, 2014. Evaluation of some physiological traits and yield of basil (Ocimum basilicum L.) under different planting dates and potassium fertilizer amounts. J. Crop. Prod. Res. 6(3): 221-230. (In Persian with English abstract).

Ghanbari A., H. Ghadiri and M. Jokar. 2006. Effect of intercropping of maize and cucumber on controlling weeds. J. Pajohesh \& Sazandegi. 73: 193-199. (In Persian with English abstract).

Ghanbari A., H. Ghadiri, M. Ghafari Moghadam and M. Safari. 2010. Evaluation of intercropping of maize (Zea mays L.) and cucurbit (Cucurbita sp.) and effect on weed control. Iran. J. Field Crops Sci. 41 (1): 43-55. (In Persian with English abstract).

Han, H. S. and K. D. Lee. 2006. Effect of inoculation with phosphate and potassium co-insolubilizing bacteria on mineral uptake and growth of pepper and cucumber. Plant Soil. Environ. 52: 130-136.

Hasanzadeh Aval, F., A. R. Koochaki, H. R. Khazaei and M. Nassiri Mahallati. 2010. Effect of density on yield and agronomic characteristics of savory and Persian clover intercropping. Iran. J. Field Cros. Res. 8(6): 920-929. (In Persian with English abstract).

Hernandez, A. N., A. Hernandez and M. Heydrich. 1995. Selection of rhizobacteria for use in maize cultivation. Cultivar Tropicales. 6: 5-8.

Jahan, M., M. B. Amiri, F. Dehghanipour and M. K. Tahami. 2013. Effects of biofertilizers and winter cover crops on essential oil production and some agroecological characteristics of basil (Ocimum basilicum L.) in an organic agrosystem. J. Iran. Agron. Res. 10(4): 751-763. (In Persian with English abstract).

Koochaki, A. and M. Khajeh Hosseini. 2008. Modern Agronomy. Jehade Daneshgahi Mashhad Press. Mashhad. (In Persian).

Letchamo, W., H. L. Xu and A. Gosselin. 1995. Photosynthetic potential of Thymus vulgaris selections under two light regimes and three soil water levels. Sci. Hort. 62: 89-101.

Mahfouz, S. A. and M. A. Sharaf-Eldin. 2007. Effect of mineral vs. biofertilizer on growth, yield, and 


$$
\text { "نشريه علوم زراعى ايران"، جلد بيست و يكم، شماره "ا، باييز شجسا }
$$

essential oil content of fennel (Foeniculum vulgare Mill.). Int. Agrophys. 21: 361-366.

Malakouti, M. J. 1998. Comprehensive approach is recommended diagnosis and optimal use of fertilizers for plants. Tarbiat Modarres University Press. Tehran. (In Persian).

McGuirk, S. M. and S. D. Semard. 2005. Toxicologic emergencies in cattle. Veterinary clinics of North America. Food. Anim. Practic. 21: 729-749.

Nanda S. S., K. C. Swain, S. C. Panda, A. K. Mohanty and M. A. Alim. 1995. Effect of nitrogen and biofertilizers in fodder rainfed upland conditions of Orisa. Current. Agric. Res. 8: 45-47.

Nour Gholipour, F., Y. R. Bagheri and M. Lotf Allahi. 2009. Effect of different nitrogen fertilizer sources on yield and quality of wheat. J. Res. Agric. Sci. 4(2): 120-129. (In Persian with English abstract).

Omidbaigi, R. 2006. Production and Processing of Medicinal Plants. Astan Ghods Razavi Press. Mashhad. (In Persian).

Pandey, R. K., J. W. Maranville and A. Admou. 2000. Deficit irrigation and nitrogen effects on maize in a Sahelian environment. I. Grain yield and yield components. Agric. Water. Manage. 46: 1-13.

Raei, Y., S. Kordi, F. Ghanbari, A. A. Shayan, G. Shahkarami and S. Fatahi. 2015. The effect of Azospirilium bacteria and salicylic acid effects on drought stress tolerance in Ocimum basilicum L. medicinal plant. Adv. Bioresour. 6(6): 44-53.

Rajeswara Rao, B. R. 2002. Biomass yield, essential oil yield and essential oil composition of rose-scented geranium (Pelargonium species) as influenced by row spacings and intercropping with cornmint (Mentha arvensis L.f. piperascens Malinv. ex Holmes). Ind. Crop. Prod. 16: 133-144.

Rezayi Chiyaneh A. and A. Dabbagh Mohammadi Nassab. 2014. Evaluation of application of biological and chemical fertilizers on quality and quantity yield of ammi. Agric. Eco, 6(3): 582-594. (In Persian with English abstract).

Rezaei Moadab, A. R., M. Nabavi Kalat and R. Sadrabadi Haghighi. 2014. The effect of vermicompost and biological and chemical fertilizers on growth yield and essence of basil (Ocimum basilicum L.) in the Mashhad weather conditions. J. Ecol. Agric. 5(4): 350-362. (In Persian with English abstract).

Shakiba, M. R., R. Amini, S. Sakhavi and A. Dabbagh Mohammadi Nasab. 2016. Advantage of faba bean (Vicia faba L.) and cumin (Cuminum cyminum L.) intercropping under organic, biological and chemical fertilizer treatments. J. Agric. Sci. Sustain. Prod. 26(4): 17-32. (In Persian with English abstract).

Thorsted, M. D., J. E. Olesen and J. Weiner. 2006. Width of clover strips and wheat rows influence grain yield in winter wheat/white clover intercropping. Field. Crops Res. 95: 280-290.

Vessey, J. K. 2003. Plant growth promoting rhizobacteria as biofertilizers. Plant. Soil. 255: 571-586.

Zahir A. Z., S. A. Abass, A. Khalid and M. Arshad. 2000. Substrate depended microbially derived plant hormones for improving growth of maize seedling. Pak. J. Biol. Sci. 3: 289-291. 


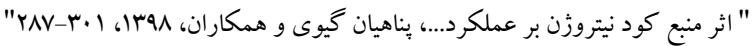

\title{
Effect of nitrogen fertilizer source on yield and essential oil content of sweet basil (Ocimum basilicum L.) and forage maize (Zea mays L.) yield in intercropping
}

\section{Panahyan, M. ${ }^{1}$, S. Kordi ${ }^{2}$ and J. Davarpanah ${ }^{3}$}

\begin{abstract}
Panahyan, M., S. Kordi and J. Davarpanah. 2019. Effect of nitrogen fertilizer source on yield and essential oil content of sweet basil (Ocimum basilicum L.) and forage maize (Zea mays L.) yield forage in intercropping. Iranian Journal of Crop
\end{abstract} Sciences. 21(3):287-301. (In Persian).

To evaluate the effect of nitrogen sources on yield and quality of sweet basil and forage maize under intercropping (additive series), a field experiment was carried out at the experimental field of faculty of agriculture, Lorestan University, Khorramabad, Iran, in 2013-2014 and 2014-2015 growing seasons. Experimental treatments were arranged as factorial in randomized complete block design with three replications. Experimental treatments included: without fertilizer (Control), 100\% chemical fertilizer (N), bio-fertilizer (Nitroxin), integration of bio-fertilizer $+50 \%$ chemical fertilizer, and cropping patterns consisted of; sole cropping sweet basil and forage maize and the additive intercropping of maize $+25 \%$ sweet basil, maize $+50 \%$ sweet basil, maize $+75 \%$ sweet basil and maize $+100 \%$ sweet basil. Mean comparisons showed that in the second year sole cropping of sweet basil with $100 \%$ chemical fertilizer in second harvest had the highest total dry weight (3921.9 kg.ha-1). Among cropping systems the highest total dry weight $\left(19220 \mathrm{~kg}^{-1} \mathrm{ha}^{-1}\right)$ was obtained from sole cropping of forage maize. Application of the integration of Nitroxin $+50 \%$ nitrogen chemical fertilizer in intercropping produced reasonable biological yield and essential oil yield, and did not show a remarkable difference with nitrogen chemical fertilizer. The highest LER (1.566) belonged to maize $+100 \%$ sweet basil with bio-fertilizer. The results showed that using the integration of bio-fertilizer $+50 \%$ chemical fertilizer can be considered as an enviromnet-friendly approach to reduce the consumption of chemical fertilizers in support of sustainable agriculture.

Key words: Biofertilizer, Forage maize, Interropping ratios, Land equivalent ratio and Sweet basil.

\footnotetext{
Received: April, 2018 Accepted: June, 2019

1. Assistant Prof., Agriculture Department, Payam Nour University, Iran (Corresponding author)

(Email: mehdi.panahyan2018@gmail.com)

2. Member of Young Researcher and Elite Club, Khorramabad Barnch, Islamic Azad University, Khorramabd, Iran

3. MSc in Genetics and Animal Breeding, Ferdowsi University of Mashhad, Mashhad, Iran
} 